\title{
Land Suitability Assessment for Pulse (Green Gram) Production through Remote Sensing, GIS and Multicriteria Analysis in the Coastal Region of Bangladesh
}

\author{
Billal Hossen ${ }^{1,2}$, Helmut Yabar ${ }^{1, *}$ and Takeshi Mizunoya ${ }^{1} \mathbb{C}$ \\ 1 Graduate School of Life and Environmental Sciences, University of Tsukuba, 1-1-1 Tennodai, \\ Tsukuba 305-8572, Ibaraki, Japan; billalhossen84@yahoo.com (B.H.); \\ mizunoya.takeshi.ff@u.tsukuba.ac.jp (T.M.) \\ 2 Department of Agricultural Extension (DAE), Khamarbari, Farmgate, Dhaka 1215, Bangladesh \\ * Correspondence: yabar.mostacero.h.ke@u.tsukuba.ac.jp; Tel.: +81-29-853-4269
}

Citation: Hossen, B.; Yabar, H.; Mizunoya, T. Land Suitability Assessment for Pulse (Green Gram) Production through Remote Sensing, GIS and Multicriteria Analysis in the Coastal Region of Bangladesh. Sustainability 2021, 13, 12360. https:// doi.org/10.3390/su132212360

Academic Editor: Piotr Prus

Received: 22 September 2021

Accepted: 4 November 2021

Published: 9 November 2021

Publisher's Note: MDPI stays neutral with regard to jurisdictional claims in published maps and institutional affiliations.

Copyright: () 2021 by the authors. Licensee MDPI, Basel, Switzerland. This article is an open access article distributed under the terms and conditions of the Creative Commons Attribution (CC BY) license (https:// creativecommons.org/licenses/by/ $4.0 /)$.

\begin{abstract}
The agricultural potential of Bangladesh's coastal region has been threatened by the impact of climate change. Pulse crops with high nutritional value and low production costs such as green gram constitute an important component of a healthy and accessible diet for the country. In order to optimize the production of this important staple, this research aims to promote climate-smart agriculture by optimizing the identification of the appropriate land. The objective of this research is to investigate, estimate, and identify the suitable land areas for green gram production based on the topography, climate, and soil characteristics in the coastal region of Bangladesh. The methodology of the study included a Geographic Information System (GIS) and the Multicriteria Decision-Making approach: the Analytical Hierarchy Process (AHP). Datasets were collected and prepared using Landsat 8 imagery, the Center for Hydrometeorology and Remote Sensing (CHRS) data portal and the Bangladesh Agricultural Research Council. All the datasets were processed into raster images and then reclassified into four classes: Highly Suitable (S1), Moderately Suitable (S2), Marginally Suitable (S3), and Not Suitable. Then, the AHP results were applied to produce a final green gram suitability map with four classes of suitability. The results of the study found that $12 \%$ of the coastal area $(344,619.5 \mathrm{ha})$ is highly suitable for green gram production, while the majority of the land area (82.3\% of the area) shows moderately suitable (S2) land. The sensitivity analysis results show that $3.3 \%, 63.4 \%, 28.0 \%$, and $1.2 \%$ of the study area are $\mathrm{S} 1, \mathrm{~S} 2, \mathrm{~S} 3$, and NS, respectively. It is also found that the highly suitable land area belongs mostly to the southeastern part of the country. The result of this study can be utilized by policymakers to adopt a proper green gram production strategy, providing special agricultural incentive policies in the highly suitable area as a provision for the increased food production of the country.
\end{abstract}

Keywords: Bangladesh's coastal region; green gram land suitability; sustainable agriculture; Geographic Information System (GIS); Analytical Hierarchy Process (AHP)

\section{Introduction}

Bangladesh, due to its geographical location and social circumstances, is one of the world's most disaster-prone countries [1-4]. Various natural disasters, such as intense rainfall, cyclones, flooding, thunderstorms, tornadoes, storm surges, salinity intrusion, and others, have already occurred in this country, and the intensity of these disasters has been rising in coastal Bangladesh [5]. Coastal areas are more vulnerable to disasters than other parts of the world [6]. These hazards may lead to a variety of socioeconomic consequences in coastal areas, including loss of property and coastal habitats, reduced agricultural productivity, loss of tourism, transportation, recreation and industry, and harbor activities $[7,8]$. Non-climate stressors, such as urbanization, population migration, land-use change, pollution, and gender problems, have also been strong drivers of changes 
in coastal agriculture around the world. These will, in turn, have an effect on the long-term viability of coastal food security [9-11].

Green gram (Vigna radiata) is one of the most popular pulse crops, grown on more than six million hectares of land across the globe-representing around 8.5 percent of the global pulse cultivated area. The green gram is extensively cultivated in many Asian countries, primarily India, Bangladesh, China, Pakistan, and some Southeast Asian countries, as well as in dry regions of southern Europe and warmer regions of the USA and Canada, owing to its characteristics—such as the short duration crop (around 70 days), low-input crop, and drought tolerance $[12,13]$. Green gram serves as a rich source of protein, containing $14.6-33.0 \mathrm{~g} / 100 \mathrm{~g}$ protein and $5.9-7.6 \mathrm{mg} / 100 \mathrm{~g}$ iron [12]. Green gram is a popular food for low-income people, especially those who cannot afford animal protein, as its production cost is low. Vegetarians also consume it as a good protein in their diet [13]. Green gram, a plant-based protein, contributes substantially to reducing the effects of climate change, as plant protein generates considerably less greenhouse gas than animal protein. Plant protein production is also less expensive in terms of land and water demand than animal protein [14]. So, the cultivation of green grams in the coastal area would be part of the climate change adaptation process through the improvement of soil health and environment and, at the same time, ensuring food security.

Green gram cultivation is dominant in some coastal districts of Bangladesh compared to other parts of country. During the period of 2016-17 to 2019-20, the average annual production of green gram was 56,785 MT from the coastal area of Bangladesh, while the country's total production was 52,220 MT [15]. This figure implies that farmers of the coastal region are traditionally growing green gram over the years. However, the amount of production cannot meet the country's growing demand. In the year 2017, Bangladesh spent 143.2 thousand USD on importing 322 thousand MTs of green gram (mung bean) from abroad [16]. Bangladesh also exports green gram to some extent. In 2019 , the figure for export was the highest; the export value was US $\$ 1.82$ million, with a volume of 1.04 million MTs [16]. The government of Bangladesh has been trying to extend the area of green gram production since 2014, especially in the disaster-affected areas, providing various production inputs, incentives, and subsidies to farmers to enhance the yield [15]. There is little scientific research to identify the best suitable area for green gram production. Rather, the government's subsidies and farmers' cultivation are based on traditional knowledge. Accordingly, the maximum outcome has failed to provide the highest possible input. Along with the significance of the rise in soil salinity, soil health, which is the prime determining factor of crop cultivation in the coastal areas, has been deteriorating over the years. As a consequence, agricultural crop production, particularly rice cultivation, is sharply decreasing. So, there is a potential scope to investigate whether green gram can be produced. The identification and delineation of suitable areas for growing green gram have become critical, so that the government can give more focus and make more appropriate subsidy policies to boost green gram production, improve the environment, and ultimately reduce its import dependence by increasing domestic production.

To ensure the security of national food, recent land-use technology such as GIS and remote sensing has not been widely used in Bangladesh's agriculture, particularly in the coastal region. Accordingly, individual crop cultivation, with its potentiality in Bangladesh, requires an extensive land suitability analysis. There are very few GIS and remote sensingbased land suitability studies performed in Bangladesh, and those that exist are mostly for rice production for a specific district. No land suitability studies have been found for green gram production for the whole coastal area. Due to an increase in the spatial and spectral resolution of the sensors, satellite remote sensing has advantages, allowing the discovery and documentation of new archaeological features and sites all over the world [17]. The benefits of remote sensing mapping include a greater area coverage, a low cost, and comparatively high productivity $[18,19]$. High-resolution imagery (Landsat-8, Sentinel-2, Gaofeng-1) has become the primary source of crop area data in recent years $[20,21]$. 
Land assessment map analysis techniques have been achieved using geographical information systems (GIS) and remote sensing as a result of advancements in information and communication technology [22]. In addition, the Analytical Hierarchy Process (AHP), which has the advantage of incorporating expert views to prioritize the criteria according to weight in consistent judgments with GIS, are used to consider the influencing criteria for increasing green gram production. The AHP method, based on remote sensing and GIS, is extensively used in spatial decision-making processes, such as land suitability analysis for cassava [23]; crop insurance premiums based on land suitability [24]; investigating drought hazard using microwave and infrared datasets [25]; mapping of flood hazard areas [26]; site suitability for aquaculture [27]; and site selection for industrial, landfill, and biodigester [28,29].

Land suitability assessment is highly needed for productive planning and long-term land use in climate-vulnerable countries. It is crucial because it provides information on the potentials and limitations of land for a specific land use type in terms of crop performance. Land suitability analysis, according to Halder [30], is a method of land assessment that evaluates the level of appropriateness of land for a specific use. Cropland suitability analysis is a crucial step in ensuring that the available land resources are used to their full potential in order to practice sustainable agricultural production [30,31]. GIS is one of the most important methods for mapping and analyzing land-use suitability. Several criteria are required for land assessment, including various soil properties, land use land cover (LULC), slope, elevation, rainfall, and temperature. Different criteria, such as geology and biophysical components (i.e., geology, soil characteristics, relief, atmospheric conditions, and vegetation), as well as economic and socio-cultural conditions, are considered in a multicriteria assessment of land suitability [32]. The primary goal of land assessment is to determine the best land use for each specified land unit while also promoting environmental resource conservation for future use [33]. Many researchers have attempted to develop a standard framework for the most appropriate and efficient use of agricultural land. The Food and Agriculture Organization (FAO) [34] developed a framework for land evaluation, dividing the land into four classes, namely: highly suitable (S1), moderately suitable (S2), marginally suitable (S3), and not suitable (S4) (NS).

The Analytical Hierarchy Process (AHP) method, which was developed in the 1980s and introduced by Saaty in the mid-1970s, is one of the best methods for performing land suitability analysis [35,36]. AHP has been used in a variety of fields around the world, including government, enterprise, industry, healthcare, and education [37]. Because of its ability to integrate a large amount of heterogeneous data, GIS-based AHP has become popular in research, and obtaining the necessary weights for analysis can be relatively simple, even for a large number of criteria [31].

The primary purpose of this study is to investigate and determine the suitable land area with four suitability classes: highly, moderately, marginally, and not suitable, through GIS and considering expert opinions for green gram cultivation in the coastal region of Bangladesh. This suitability analysis could help the government make an effective subsidy program for crop production to enhance food security. This study could be a model for searching the appropriate site or land area to cultivate specific agricultural crops. Overall, it will facilitate the policymaker and agricultural extensionist in their land-use planning, to maximize the land use and achieve a sustainable agriculture in the southern area of Bangladesh.

\section{Materials and Methods}

\subsection{Study Area}

The research is carried out in the coastal area, the southern part of Bangladesh, composed of 18 districts, viz. Bagerhat, Barguna, Barishal, Bhola, Chattagram, Cox's bazar, Feni, Gopalganj, Jessore, Jhalkathi, Khulna, Lakshamipur, Madaripur, Narail, Noakhali, Patuakhali, Pirojpur, and Satkhira. The whole study area is located between $89^{\circ} 93^{\prime} \mathrm{E}$ and $21^{\circ} 23^{\prime} \mathrm{N}$, and the surface area is $47,150 \mathrm{~km}^{2}$ (Figure 1 ). Though the people of the coastal 
areas are mostly dependent on agriculture, the cropland quality is already degraded and continuously degraded because of the occurrence of natural disasters and climate change impact. Coastal Bangladesh is a hotspot for hydrometeorological disasters, where cyclones, tidal waves, drought, floods, waterlogging, saltwater intrusion, and land subsidence are common phenomena. This has a direct impact on livelihoods, since agriculture employs more than $60 \%$ of Bangladesh's population [38], and it is also a major source of income for the 40 million people who live along the coast [39].

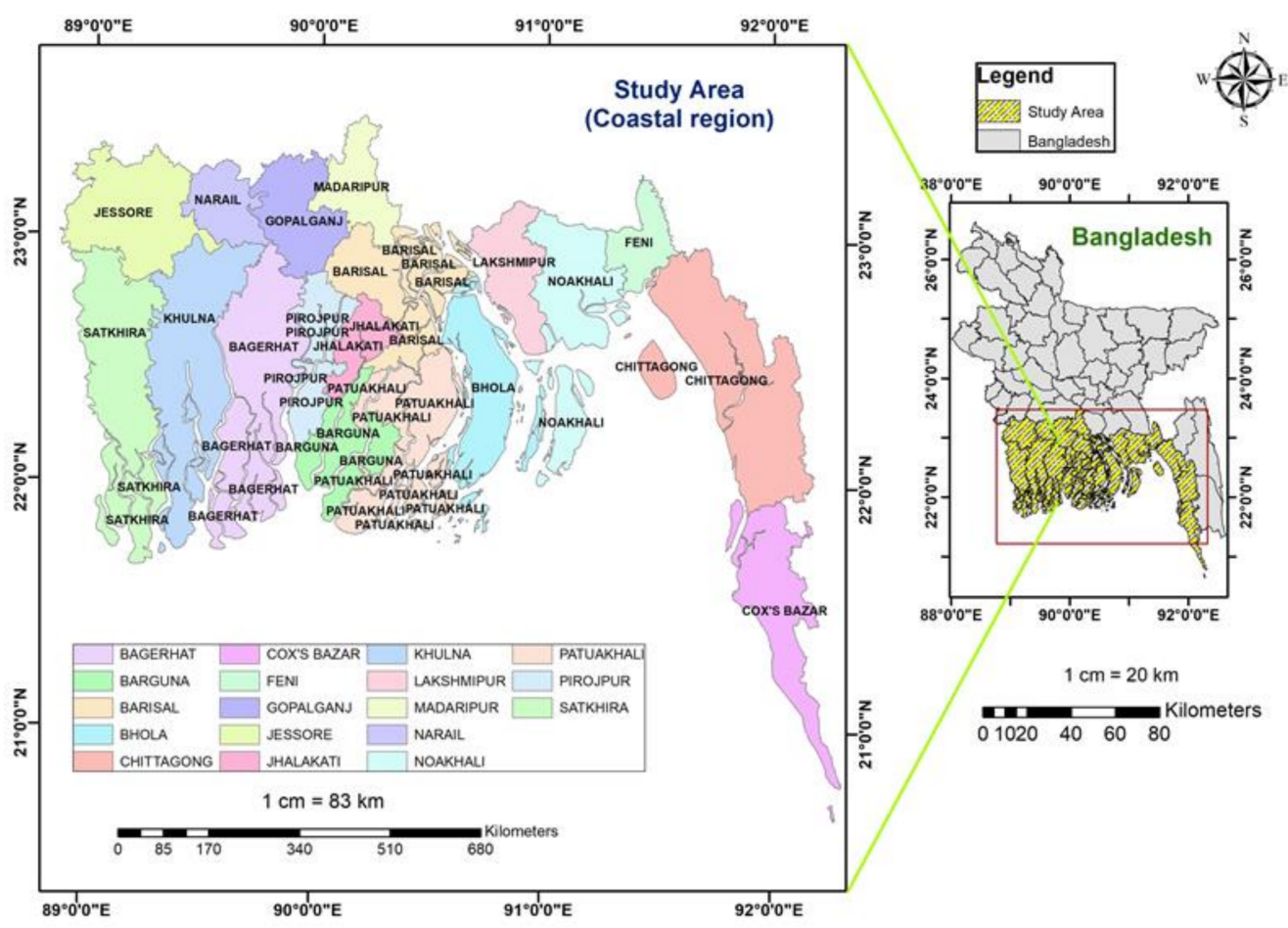

Figure 1. Study area-Coastal region of Bangladesh.

\subsection{Multicriteria Evaluation of the Land Suitability Analysis}

The assessment of land suitability for a specific use is known as land suitability analysis [40] (Food and Agriculture Organization [FAO] [41]). A land suitability assessment examines various criteria, such as the climatic, geographical, soil, vegetation, and other characteristics of lands, to determine suitable lands for specific uses $[40,41]$. One of the most critical aspects of this assessment is the definition of parameters that influence land suitability [42]. Land suitability for agricultural uses can be assessed using a variety of parameters that take into account a variety of factors, such as data availability, farming methods, the precision of evaluation, the crop type, and the environmental characteristics of the study region.

For evaluating the land suitability of pulse crop (green gram), eleven criteria (Table 1) are considered which belong mostly to topography (slope and elevation), climate (rainfall, land surface temperature), land use land cover (LULC), and soil characteristics (topsoil texture, soil drainage, soil salinity, soil $\mathrm{pH}$, soil depth, and inundation land type) based on a relevant literature review [42-46] and the opinions of experts like agriculturists, agronomists, and government personnel from the agriculture ministry. 
Table 1. Some studies on land suitability evaluation, describing the methods and the criteria considered.

\begin{tabular}{|c|c|c|c|c|}
\hline Author & Year & Methods & Crop & Criteria \\
\hline $\begin{array}{l}\text { [42] Akınc1, Ozalp, and } \\
\text { Turgut }\end{array}$ & 2013 & GIS-based AHP & All crop & $\begin{array}{l}\text { Elevation slope, aspect, land use } \\
\text { capability class and subclass, } \\
\text { various soil groups, soil erosion, } \\
\text { soil depth, OSP, }\end{array}$ \\
\hline $\begin{array}{l}\text { [47] Mishra, Deep, and } \\
\text { Choudhary }\end{array}$ & 2015 & GIS-based AHP & Organic farming & $\begin{array}{l}\text { Slope, drainage, geology, soil, } \\
\text { LULC, road }\end{array}$ \\
\hline [48] Bozdağ & 2016 & GIS-based AHP & General & $\begin{array}{c}\text { Land use, soil type, rainfall, } \\
\text { elevation, aspect, slope, sodium } \\
\text { hazard, salinity hazard, chloride, } \\
\text { water table depth }\end{array}$ \\
\hline $\begin{array}{l}\text { [43] Mugo, Kariuki, } \\
\text { Musembi }\end{array}$ & 2016 & GIS-based AHP & Green Gram & $\begin{array}{l}\text { CEC, soil depth, soil texture, soil } \\
\text { pH, soil drainage and slope }\end{array}$ \\
\hline [49] Karimi et al. & 2018 & $\begin{array}{l}\text { GIS and Multicriteria } \\
\text { Analysis }\end{array}$ & $\begin{array}{c}\text { Organic Agriculture of } \\
\text { Wheat }\end{array}$ & $\begin{array}{c}\text { Temperature, rainfall, soil texture, } \\
\text { soil depth, drainage, soil } \mathrm{pH}, \\
\text { salinity, sodicity, organi matter, } \\
\text { CEC, flood frequency, erosion, } \\
\text { slope }\end{array}$ \\
\hline [45] Habibie et al. & 2021 & $\begin{array}{l}\text { Remote sensing and } \\
\text { GIS-based } \\
\text { multi-criteria decision } \\
\text { support system }\end{array}$ & Maize & $\begin{array}{l}\text { Distance from road and rivers, } \\
\text { slope, LULC, elevation, soil type, } \\
\text { rainfall, NDVI, LST }\end{array}$ \\
\hline [44] Kumar et al. & 2019 & $\begin{array}{l}\text { Remote sensing and } \\
\text { GIS }\end{array}$ & General & $\begin{array}{l}\text { LULC, DEM, soil texture, lithology, } \\
\text { geomorphology, water level }\end{array}$ \\
\hline [46] Tashayo et al. & 2020 & GIS-AHP & Maize & $\begin{array}{l}\text { Temperature, elevation, slope, soil } \\
\text { pH, EC, CCE, ESP, and soil texture. }\end{array}$ \\
\hline
\end{tabular}

Note: EC: Electrical Conductivity; CEC: Cation Exchange Capacity; NDVI: Normalized Difference Vegetation Index; DEM: Digital Elevation Model; CCE: Calcium Carbonate Equivalent; OSP: Ontology of Soil Properties.

\subsubsection{Topography Data}

The topography of the study area refers to the slope and elevation properties of the land of the coastal area. The slope and elevation were calculated using the original Shuttle Radar Topography Mission (SRTM) and digital elevation models (DEM), which were downloaded from the USGS earth explorer in the ArcGIS environment. The topographical maps were produced and corrected the projection using the Universal Transverse Mercator (UTM) projection and the WGS 84 datum (WGS 84 46N) in the ArcGIS environment. The slope was determined by calculating the maximum rate of change between each cell and its neighbors. In the output raster, each cell had a slope value. A lower slope value means that the terrain is flatter, while a higher slope value indicates that the terrain is steeper. Flat fields had a smooth surface, which was better for crop cultivation because it made water distribution more even and fair. From Figure 2a,b, it is observed that the slope of the study area ranges from zero to $77.44 \%$, and the altitude ranges from zero to $255 \mathrm{~m}$. 


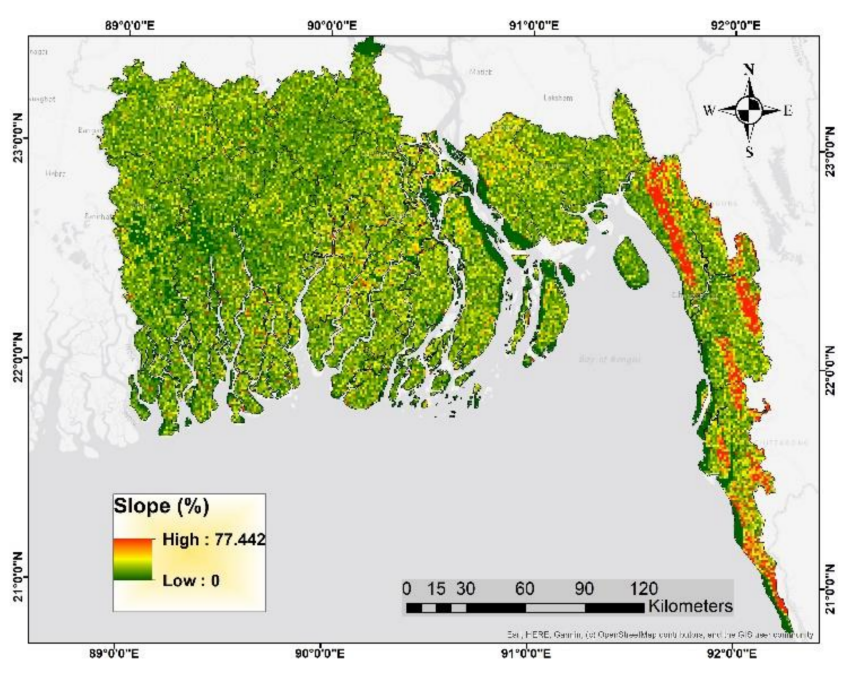

(a)

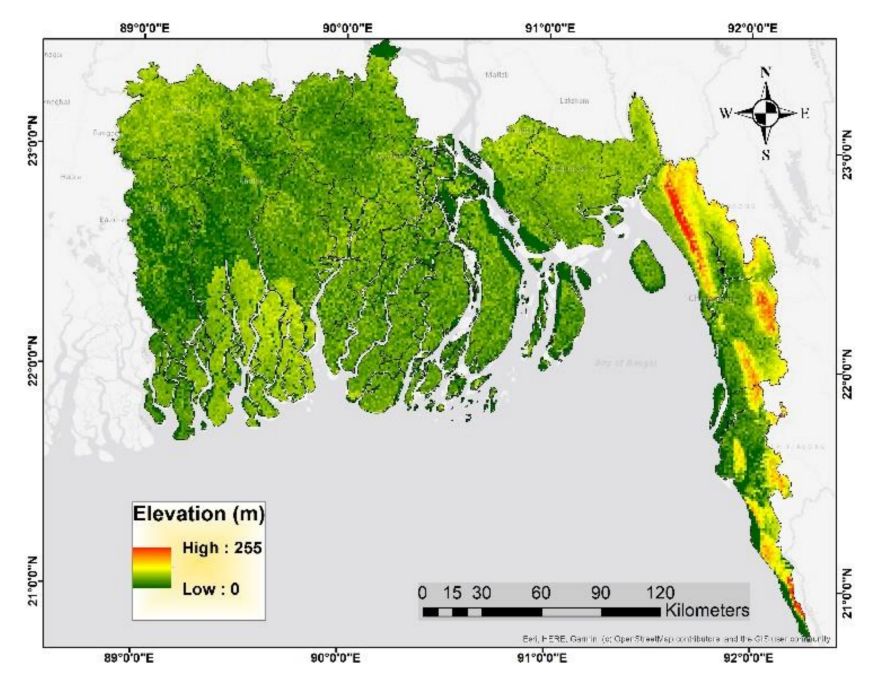

(b)

Figure 2. (a) Slope map; (b) Elevation map.

\subsubsection{Rainfall}

The rainfall data are collected from PERSIANN-CCS, of the (CHRS) data portal. The PERSIANN-Cloud Classification System (PERSIANN-CCS) is a real-time global highresolution $\left(0.04^{\circ} \times 0.04^{\circ}\right.$ or $4 \mathrm{~km} \times 4 \mathrm{~km}$;) satellite precipitation product developed by the Center for Hydrometeorology and Remote Sensing (CHRS) at the University of California, Irvine (UCI). The PERSIANN-CCS system enables the categorization of cloud-patch features based on the cloud height, areal extent, and variability of the texture estimated from satellite imagery. Rainfall raster data were downloaded for the year 2020 for the whole country, followed by an extraction by mask in ArcGIS to get the data for the study area for further reclassification. Before reclassification, the raster has been resampled to get the desired cell size, which is compatible with the cell size of other criteria.

\subsubsection{Land Surface Temperature (LST)}

Land surface temperature (LST) is an important factor that directly affects the growth and development of the plant. In this study, the mean land surface temperature map is produced through a machine learning algorithm in the Google Earth Engine (GEE) platform for the years 2018-2020. A Landsat 8 Surface Reflectance Tier 1 dataset is used, which is provided by the United States Geological Survey (USGS). The atmospherically corrected surface reflectance from the Landsat $8 \mathrm{OLI} / \mathrm{TIRS}$ sensors is included in this dataset. Five visible and near-infrared (VNIR) bands, two short-wave infrared (SWIR) bands, and two thermal infrared (TIR) bands processed to orthorectified brightness temperature are included in these images. The process to produce LST is shown in Figure 3.

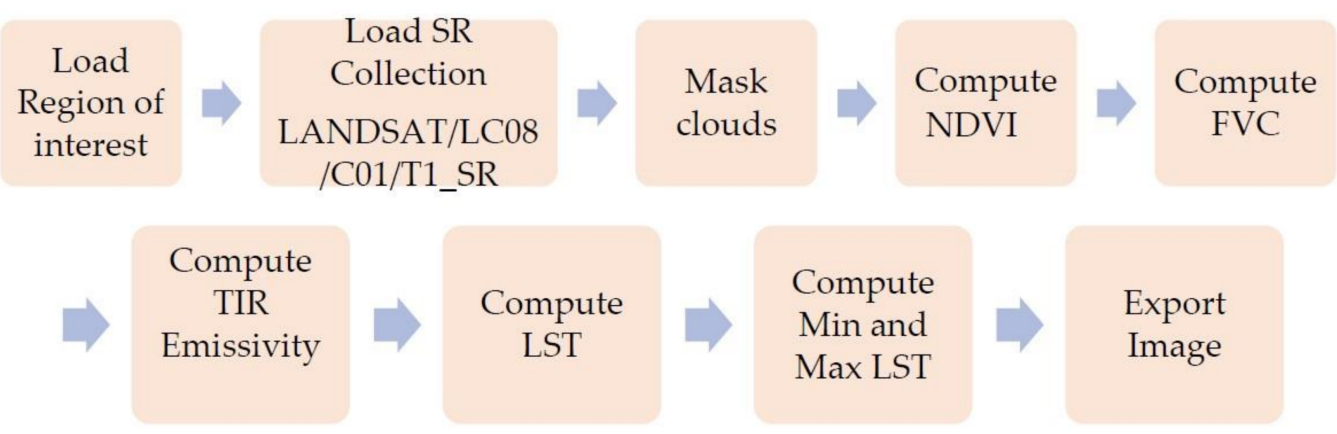

Figure 3. Flow-chart of the Land Surface Temperature (LST) map development. 
The generated LST map is exported to Google Drive and brought to the ArcGIS environment. The image of the study area is extracted by "extract by mask" and then classified into a different category. The annual mean rainfall ranged from 1069 to $2360 \mathrm{~mm}$ (Figure 4a), the minimum land surface temperature (LST) is $23.21^{\circ} \mathrm{C}$, and the maximum mean LST is $31.88^{\circ} \mathrm{C}$ (Figure $4 \mathrm{~b}$ ).

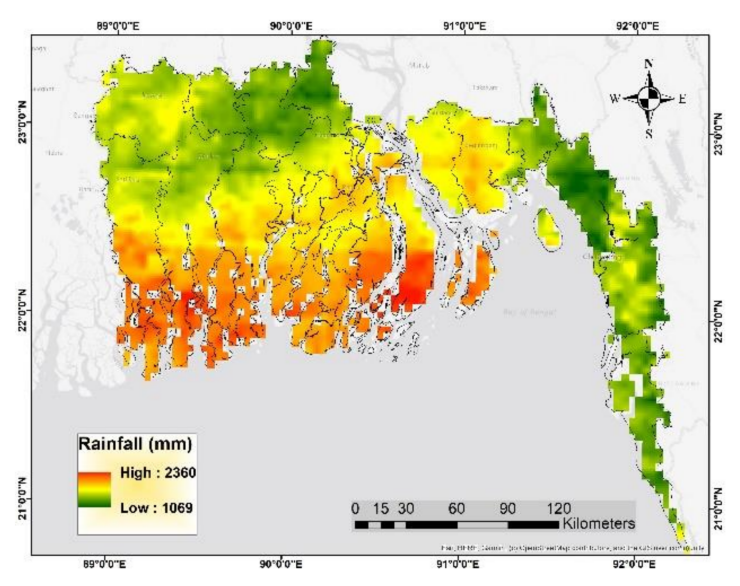

(a)

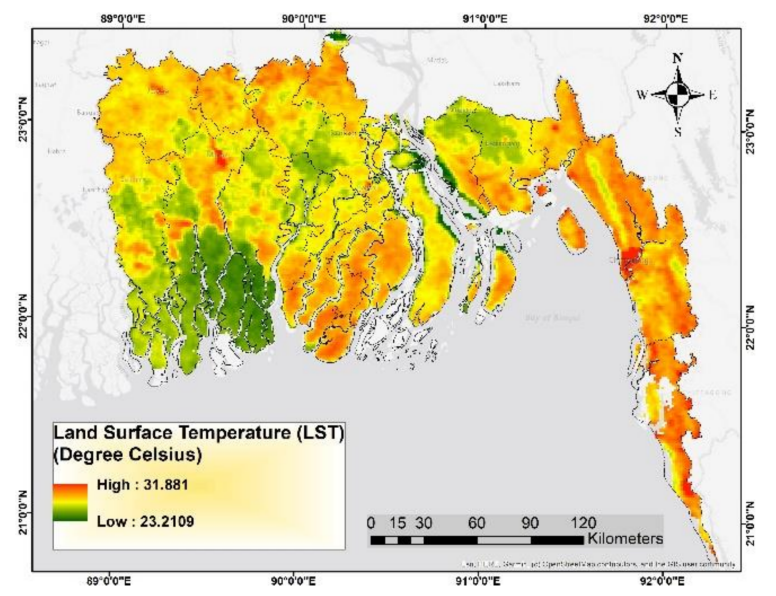

(b)

Figure 4. (a) Rainfall map; (b) Land Surface Temperature (LST) map.

\subsubsection{Soil Characteristics}

The base map for soil characteristics such as topsoil texture, soil salinity, soil $\mathrm{pH}$, soil depth, soil drainage, and inundation land type are collected from the Bangladesh Country Almanac (BCA) as vector data and imported to ArcGIS. The study area is extracted using the extract by mask function. These data are georeferenced and projected to WGS 1984 UTM $46 \mathrm{~N}$ through the projected coordinate system in ArcGIS. Next, these vector data are converted to raster data through the polygon to raster function in ArcGIS 10.7, followed by reclassification, made into various classes, according to the FAO suitability class guidelines (Table 2). They illustrated the various suitability class for each parameter.

Table 2. Structure of the FAO Land Suitability Classification.

\begin{tabular}{|c|c|c|}
\hline Symbol & Suitability Level & Description \\
\hline S1 & Highly Suitable & $\begin{array}{l}\text { Land having no significant limitations or only minor } \\
\text { limitations }\end{array}$ \\
\hline S2 & Moderately Suitable & $\begin{array}{l}\text { Land having limitations which in aggregate are } \\
\text { moderately severe/land that is clearly suitable, but } \\
\text { which has limitations either in productivity or } \\
\text { increasing the inputs needed to sustain the productivity } \\
\text { compared with those needed on S1 land }\end{array}$ \\
\hline S3 & Marginally Suitable & Land having limitations which in aggregate are severe \\
\hline NS & Not Suitable & Land having severe limitations \\
\hline
\end{tabular}

Source: Guidelines for land-use planning [50].

\subsubsection{Land Use Land Cover}

This study also includes the preparation of Land Use Land Cover classifications. This was also done in the Google Earth engine platform; an analysis based on the machine learning algorithm, using the Landsat 8 dataset that is described as Landsat 8 Collection 1 Tier 1 calibrated top-of-atmosphere (TOA) reflectance with a cloud cover below $1 \%$. The process started by loading the Region of Interest (ROI) and collecting the Landsat 8 dataset for each ROI. Next, all images were merged using the mosaic function, followed by clipping the mosaic data by the study area boundary. Then, training data were collected by collecting 
the sample points across the entire study area. Sample points or features are assembled with a property, storing the known class label and properties that store numeric values for the predictors. A smile cart classifier was used which is trained with training data followed by the classification of the image or feature. The accuracy assessment was done using the Confusion Matrix function, and a $99.3 \%$ accuracy was estimated. Finally, the produced image was exported. This land use land classification is a supervised classification. Then, this map was imported to the ArcGIS environment, which was followed by the resampling of raster data to make the cell size compatible with other data. A reclassification assigning the score was done to use in AHP. Finally, the raster data were changed to a projected coordinate system with UTM WGS 84, and the area was calculated for each class. The flow chart of the process is shown as Figure 5. In the map, five Land Use Land Cover classes, viz. forest, water, agricultural land, bare/fallow land, and settlement, were produced (Figure 6).

\begin{tabular}{|c|c|c|c|c|c|c|c|c|}
\hline $\begin{array}{c}\text { Load } \\
\text { Region of } \\
\text { interest }\end{array}$ & $\Rightarrow$ & $\begin{array}{c}\text { Load } \\
\text { LANDSA } \\
\text { T/LC08/C } \\
\text { 01/T1_T } \\
\text { OA_ }\end{array}$ & $\Rightarrow$ & $\begin{array}{c}\text { Merge } \\
\text { different } \\
\text { image into one } \\
\text { using mosaic } \\
\text { function }\end{array}$ & $\Rightarrow$ & $\begin{array}{l}\text { Clip } \\
\text { mosaic } \\
\text { data by } \\
\text { study } \\
\text { area }\end{array}$ & $\Rightarrow$ & $\begin{array}{c}\text { Training } \\
\text { data } \\
\text { Collection }\end{array}$ \\
\hline
\end{tabular}

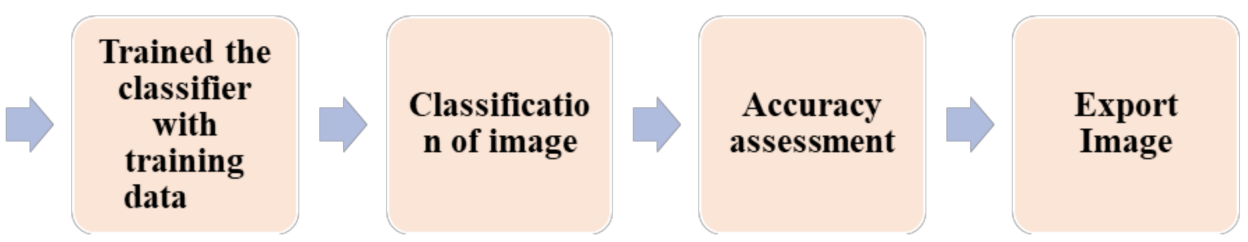

Figure 5. Flow-chart of the Land Use Land Cover (LULC) map development.

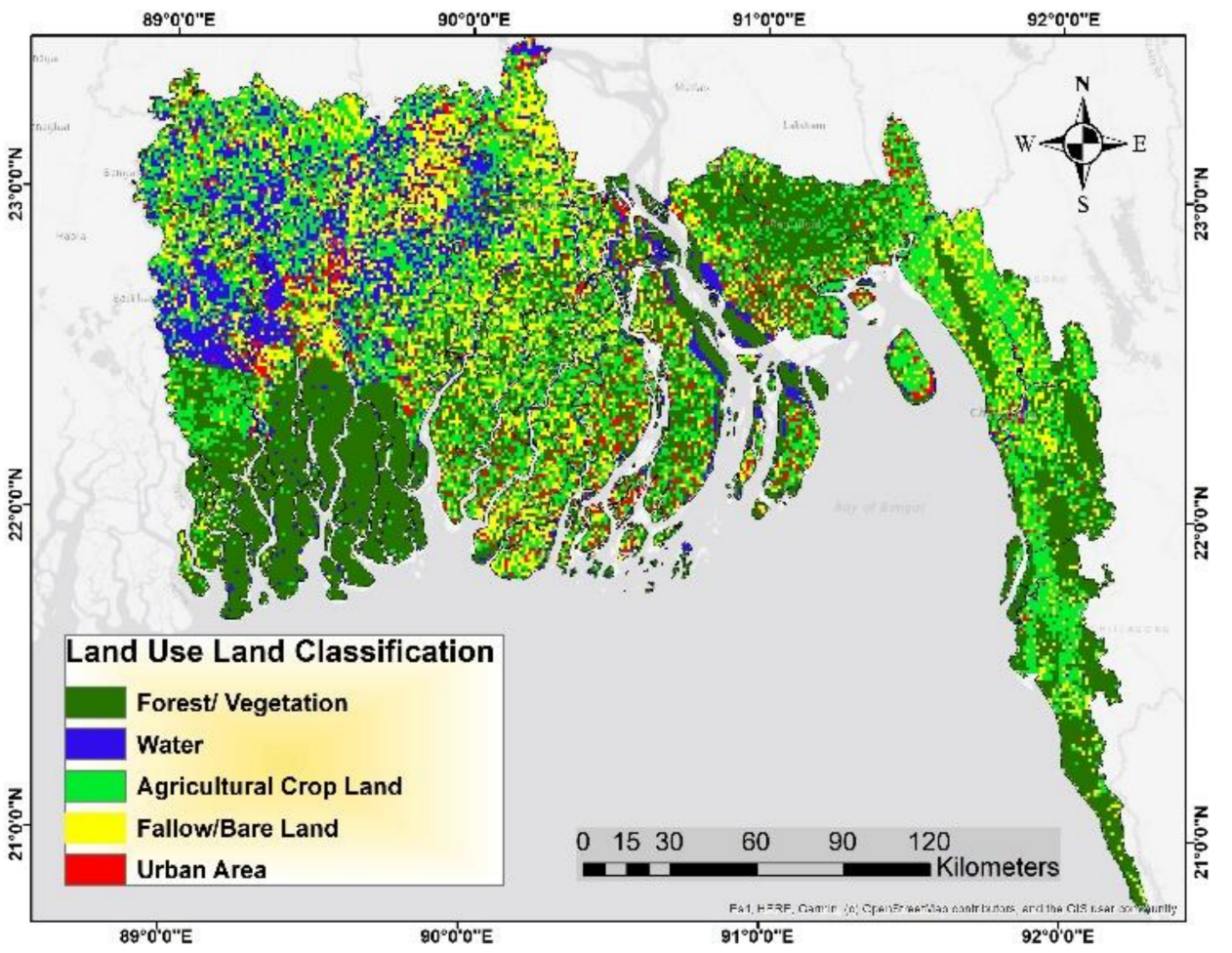

Figure 6. Land Use Land Cover (LULC). 


\subsection{Reclassification of All Parameters}

All the parameters described above were reclassified using the reclassify function in ArcGIS into four classes, namely, highly suitable (S1), moderately suitable (S2), marginally suitable (S3), and not suitable (NS), according to the FAO suitability guideline [50] (Tables 2 and 3). Finally score was assigned to each class of each parameter. The reclassified criteria illustrate the areal and spatial distribution of the various suitability levels of the criteria. The priority levels among the criteria were determined with the help of the AHP analysis, and a weight was assigned to each criterion. This was followed by the deployment of a weight overlay in ArcGIS and the development of a final suitability map. The entire process was carried out in a model builder, which is shown in Appendix A. The area in hectares was calculated for each individual class of each criterion and for each class of the final suitability map.

Table 3. Parameters used, data range, and suitability class.

\begin{tabular}{|c|c|c|c|c|c|}
\hline S1 No. & Parameters & Highly Suitable (S1) & Moderately Suitable (S2) & Marginally Suitable (S3) & Not Suitable (NS) \\
\hline 1 & Slope (\%) & $0-3 \%$ & $3-9 \%$ & $9-22 \%$ & $>22 \%$ \\
\hline 2 & Elevation (m) & $<50$ & $51-100$ & $100-200$ & $>200$ \\
\hline 3 & $\begin{array}{l}\text { Temperature } \\
\text { (OC) }\end{array}$ & $26-30$ & $25-26$ & $23.2-25$ & $>30$ \\
\hline 4 & $\begin{array}{l}\text { Precipitation } \\
\quad(\mathrm{mm})\end{array}$ & $1069-1500$ & $1500-1600$ & $1600-1800$ & $1800-2360$ \\
\hline 5 & $\begin{array}{l}\text { Topsoil } \\
\text { Texture }\end{array}$ & Loam/Silt/silt Loam & $\begin{array}{c}\text { Silty Clay/Silty clay Loam } \\
\text { \& clay }\end{array}$ & Predominantly clay & Muck/Peat/Sand \\
\hline 6 & Soil $\mathrm{pH}$ & $5.5-7.3$ & $7.3-8.4$ & $7.3-8.4 / 4.5-5.5$ & $<4.5 \&>8.4$ \\
\hline 7 & Land Type & $\begin{array}{l}\text { Highland/Medium } \\
\text { Highland }\end{array}$ & Medium low land & Lowland & Very Lowland \\
\hline 8 & Soil Depth (m) & $>1.22$ & $0.9-1.22$ & $0.25-0.9$ & $<0.25$ \\
\hline 9 & $\begin{array}{l}\text { Soil Salinity } \\
(\mathrm{mmhos} / \mathrm{cm})\end{array}$ & $<2$ & $2-4$ & $4-8$ & $8-15$ \\
\hline 10 & Soil Drainage & Well Drained & Moderately Drained & Poorly Drained & $\begin{array}{l}\text { Very Poorly } \\
\text { Drained }\end{array}$ \\
\hline 11 & $\begin{array}{l}\text { Land Use } \\
\text { Land Cover }\end{array}$ & $\begin{array}{l}\text { Agricultural } \\
\text { Cropland }\end{array}$ & Fallow/Bare land & Forest Vegetation & Water/Urban \\
\hline
\end{tabular}

\subsection{Preference of the Criteria/Parameters in the Decision-Making Process}

The preference of parameters can be described by the weights, assigning the weight (value) to each criterion. The objective of weighting is to represent the relative importance of each criterion to others on the growth and development of plants and crop yield. Based on the review of literature and opinions from experts, especially agriculturists and agronomists, critical requirements for pulse (green gram) production are identified and the relative importance of each criterion to others is determined. This process is referred to as Multicriteria Decision Approach.

The process of the Multicriteria Decision Approach contains several phases. At first, various factors and constraints for crop production were identified [51]. Next, a pairwise comparison matrix was constructed using the abovesaid factors. Among the various approaches in the development of weight, the Analytical Hierarchy Process (AHP), a pairwise comparison matrix in the context of a decision-making process, was used in this study. The comparison determines the relative importance of two criteria associated in determining the suitability of the stated objective [51].

\subsection{Analytical Hierarchy Process (AHP)}

The Analytic Hierarchy Process (AHP), which was developed by Saaty [52], was applied to resolve highly complex decision-making problems which involve multiple scenarios, criteria, and factors [53]. In terms of both the qualitative and quantitative aspects of decision-making, the AHP is one of the most powerful and flexible decision-making processes, allowing people to set priorities and make the best decision [54]. 
The AHP is a commonly used protocol that is widely recognized as the most reliable multicriteria decision-making technique [55]. The method was applied to a series of parameters in order to create a hierarchical structure by assigning a weight to each parameter in the entire decision-making process [56]. As a result, a number of decisionmaking approaches attempt to determine the relative value, or weight, of the alternatives in terms of each parameter in each decision-making problem. According to Saaty [57], the AHP establishes a structural foundation for quantifying the robust comparison of design factors in a pairwise technique, thereby decreasing the complexity of the decision-making process. The priority of the variables (elevation, slope, rainfall, land surface temperature, inundation land type, soil $\mathrm{pH}$, soil drainage, topsoil textures, soil salinity, soil depth, and LULC) was determined using weights, and the suitability of various land uses for pulse production was determined using weights. For the weighted overlay applications using GIS, the resulting AHP weights were used to calculate the priority of each factor. The parameters/criteria of the decision model were arranged into a hierarchy for land suitability in the first stage of the analysis. The criteria were then scored using pairwise comparisons and relative importance scoring scales in the second stage (Table 4). A fundamental 9-point scale measurement is used in AHP to express individual preferences or judgments [57], creating a matrix of pairwise comparisons (Table 5). These pairwise comparisons simplify the decision-making process by allowing independent analyses of each factor's impact [58].

Table 4. The comparison scale in AHP [56].

\begin{tabular}{|c|c|c|}
\hline Degree of Importance & Definition & Explanation \\
\hline 1 & $\mathrm{i}$ and $\mathrm{j}$ are equally important. & $\begin{array}{l}\text { Two acts are equally } \\
\text { important in achieving the } \\
\text { goal. }\end{array}$ \\
\hline 3 & i has lower importance than $\mathrm{j}$. & $\begin{array}{l}\text { One activity has a modest } \\
\text { advantage over another based } \\
\text { on experience and judgment. }\end{array}$ \\
\hline 5 & $\begin{array}{l}\text { Substantial importance of } \mathrm{i} \\
\text { over } \mathrm{j}\end{array}$ & $\begin{array}{l}\text { One activity has a } \\
\text { considerable advantage over } \\
\text { another based on experience } \\
\text { and judgment. }\end{array}$ \\
\hline 7 & $\begin{array}{l}\text { Remarkable importance of } \mathrm{i} \\
\text { over } \mathrm{j}\end{array}$ & $\begin{array}{l}\text { In practice, an action is greatly } \\
\text { preferred, and its domination } \\
\text { is evident. }\end{array}$ \\
\hline 9 & $\begin{array}{l}\text { The absolute importance of } \mathrm{i} \\
\text { over } \mathrm{j}\end{array}$ & $\begin{array}{l}\text { The evidence that favors one } \\
\text { action over another is of the } \\
\text { greatest possible quality. }\end{array}$ \\
\hline $2,4,6,8$ & $\begin{array}{c}\text { The two neighboring } \\
\text { Judgments have intermediate } \\
\text { values. }\end{array}$ & $\begin{array}{l}\text { When there is a necessity for } \\
\text { compromise }\end{array}$ \\
\hline Above-Nonzero Reciprocals & $\begin{array}{l}\text { When compared to activity } \mathrm{j} \text {, } \\
\text { if activity } \mathrm{i} \text { has one of the } \\
\text { above nonzero numbers } \\
\text { assigned to it, then } \mathrm{j} \text { has the } \\
\text { reciprocal value. }\end{array}$ & \\
\hline
\end{tabular}

The comparative results (for each pair) are expressed as a number ranging from 1 (equal) to 9 (extremely different), while a higher value means that the chosen criteria are more important compared to other factors. A score of 9 means that the row factor is more important in comparison with the column factor. A rating of $1 / 9$, on the other hand, means that the importance of the row factor is less than that of the column factor [59]. A value of 1 is given when the column and row elements are equally important. When comparing soil salinity and slope parameters, for example, a score of 1 means they were equally significant 
in assessing appropriateness, while a score of 9 suggests that soil salinity is more significant than slope. The diagonal and reciprocal scores were placed in the lower left triangle of a pairwise comparison matrix, which included all of the scores. When the row factor was found to be less significant than the column factor, reciprocal values $(1 / 3,1 / 5,1 / 7$, and 1/9) were used (Table 5).

Table 5. Pairwise comparison matrix.

\begin{tabular}{|c|c|c|c|c|c|c|c|c|c|c|c|}
\hline Criteria & $\begin{array}{c}\text { Soil } \\
\text { Salinity }\end{array}$ & $\begin{array}{c}\text { Soil } \\
\text { Drainage }\end{array}$ & $\begin{array}{l}\text { Soil } \\
\text { pH }\end{array}$ & $\begin{array}{c}\text { Soil } \\
\text { Texture }\end{array}$ & $\begin{array}{c}\text { Soil } \\
\text { Depth }\end{array}$ & $\begin{array}{c}\text { Inundation } \\
\text { Type }\end{array}$ & Rainfall & LST & LULC & Elevation & Slope \\
\hline Soil salinity & 1.00 & 3.00 & 4.00 & 4.00 & 5.00 & 6.00 & 7.00 & 8.00 & 8.00 & 9.00 & 9.00 \\
\hline $\begin{array}{c}\text { Soil } \\
\text { Drainage }\end{array}$ & $1 / 3$ & 1.00 & 2.00 & 3.00 & 4.00 & 5.00 & 5.00 & 7.00 & 8.00 & 9.00 & 9.00 \\
\hline Soil pH & $1 / 4$ & $1 / 2$ & 1.00 & 2.00 & 3.00 & 4.00 & 5.00 & 6.00 & 7.00 & 8.00 & 8.00 \\
\hline Soil Texture & $1 / 4$ & $1 / 3$ & $1 / 2$ & 1.00 & 2.00 & 3.00 & 5.00 & 6.00 & 6.00 & 6.00 & 7.00 \\
\hline Soil Depth & $1 / 5$ & $1 / 4$ & $1 / 3$ & $1 / 2$ & 1.00 & 3.00 & 4.00 & 5.00 & 5.00 & 5.00 & 6.00 \\
\hline $\begin{array}{l}\text { Inundation } \\
\text { type }\end{array}$ & $1 / 6$ & $1 / 5$ & $1 / 4$ & $1 / 3$ & $1 / 3$ & 1.00 & 2.00 & 3.00 & 3.00 & 4.00 & 5.00 \\
\hline Rainfall & $1 / 7$ & $1 / 5$ & $1 / 5$ & $1 / 5$ & $1 / 4$ & $1 / 2$ & 1.00 & 2.00 & 2.00 & 3.00 & 4.00 \\
\hline LST & $1 / 4$ & $1 / 7$ & $1 / 6$ & $1 / 6$ & $1 / 5$ & $1 / 3$ & $1 / 2$ & 1.00 & 2.00 & 3.00 & 3.00 \\
\hline LULC & $1 / 8$ & $1 / 8$ & $1 / 7$ & $1 / 6$ & $1 / 5$ & $1 / 3$ & $1 / 2$ & $1 / 2$ & 1.00 & 2.00 & 3.00 \\
\hline Elevation & $1 / 9$ & $1 / 9$ & $1 / 8$ & $1 / 6$ & $1 / 5$ & $1 / 4$ & $1 / 3$ & $1 / 3$ & $1 / 2$ & 1.00 & 2.00 \\
\hline Slope & $1 / 9$ & $1 / 9$ & $1 / 8$ & $1 / 7$ & $1 / 6$ & $1 / 5$ & $1 / 4$ & $1 / 3$ & $1 / 3$ & $1 / 2$ & 1.00 \\
\hline
\end{tabular}

Third, we calculated the matrix and double-checked the consistency of the pairwise comparison factors. The AHP also included measurements for calculating the normalized values of each factor, as well as the normalized principal eigenvalue and priority vectors. The pairwise matrix was computed and can be expressed as follows:

$$
\left[\begin{array}{ccccc}
\mathrm{C} 11 & \mathrm{C} 12 & & & \mathrm{C} 1 \mathrm{n} \\
\mathrm{C} 21 & \mathrm{C} 22 & \cdot & \cdot & \mathrm{C} 2 \mathrm{n} \\
\cdot & \cdot & \cdot & \cdot & \cdot \\
\cdot & \cdot & \cdot & \cdot & \cdot \\
\mathrm{Cn} 1 & \mathrm{Cn} 2 & \cdot & \cdot & \mathrm{Cnn}
\end{array}\right]
$$

Next, The pairwise matrix's sum for each column was calculated as follows:

$$
\mathrm{Cij}=\sum_{\mathrm{i}=1}^{\mathrm{n}} \mathrm{Cij}
$$

To create a normalized pairwise matrix, each element of the matrix is divided by its column total as follows:

$$
X_{i j}=\frac{C_{i j}}{\sum_{i=1}^{n} C_{i j}}=\left[\begin{array}{ccccc}
X 11 & X 12 & & X 1 n \\
X 21 & X 22 & \cdot & \cdot & X 2 n \\
\cdot & \cdot & \cdot & \cdot & \cdot \\
\cdot & \cdot & \cdot & \cdot & \cdot \\
X n 1 & X n 2 & \cdot & \cdot & X n n
\end{array}\right]
$$

Finally, the weighted matrix of priority factors is calculated by dividing the column sum of the normalized matrix by the number of factors (n), as follows:

$$
W_{i j}=\frac{\sum_{j=1}^{n} X_{i j}}{n}=\left[\begin{array}{c}
W 11 \\
W 12 \\
\cdot \\
\cdot \\
W 1 n
\end{array}\right]
$$


Consistency:

It is vital to double-check the consistency of judgments after they have been entered. The following example best illustrates the concept of consistency: If an orange is twice as good as a lemon, and a lemon is twice as good as a guava, how much would we prefer an orange with respect to a guava? The answer is 4 , which is mathematically correct. Similarly, if we give the first criterion a value of 2 over the second and the second criterion a value of 3 with respect to the third in the pairwise comparison matrix, the value of preference for the first criterion with respect to the third should be $2 \times 3=6$. If the decision-maker assigned a value of 4,5 , or 7 , however, there would be some inconsistency in the matrix of judgments. In AHP analysis, some inconsistency is expected and accepted [60].

Some errors in the final matrix of judgments are unavoidable because the quantitative values are derived from individual subjective choices. It's a matter of deciding how much inconsistency is acceptable. In this regard, AHP derives a consistency ratio (CR) by comparing the consistency index $(\mathrm{CI})$ of the matrices in issue (the ones containing our judgments) to the consistency index of a random-like matrix (RI). A random matrix is one in which the judgments are input at random, and as a result, it is likely to be highly inconsistent. To be specific, Random Index (RI) is the mean of CI of 500 randomly filled in matrices [60]. Table 6 shows the calculated RI value for matrices of various sizes, as calculated by Saaty [61].

Table 6. Random index (RI) values for different numbers of elements matrix [58].

\begin{tabular}{cccccccccccc}
\hline $\mathbf{N}$ & $\mathbf{1}$ & $\mathbf{2}$ & $\mathbf{3}$ & $\mathbf{4}$ & $\mathbf{5}$ & $\mathbf{6}$ & $\mathbf{7}$ & $\mathbf{8}$ & $\mathbf{9}$ & $\mathbf{1 0}$ & $\mathbf{1 1}$ \\
\hline $\begin{array}{c}\text { Random Consistency } \\
\text { Index (RI) }\end{array}$ & 0 & 0 & 0.58 & 0.90 & 1.12 & 1.24 & 1.32 & 1.41 & 1.45 & 1.49 & 1.51 \\
\hline
\end{tabular}

The consistency ratio in AHP is denoted by the letters CR, where CR $=\mathrm{CI} / \mathrm{RI}$. According to Saaty [61], a consistency ratio (CR) of 0.10 or below is sufficient to continue the AHP analysis. If the consistency ratio is more than 0.10 , it is required to review the judgments in order to identify and address the source of the inconsistency.

The initial consistency vectors were calculated by multiplying the pairwise matrix by the weights vector in the following way:

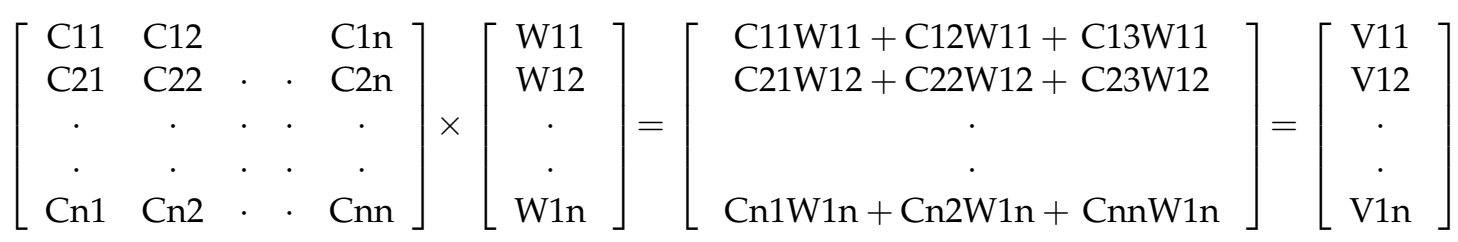

The principal eigenvector $\left(\lambda_{\max }\right)$ was computed as follows:

$$
\lambda \max =\sum_{\mathrm{i}=1}^{\mathrm{n}} \mathrm{CVij}
$$

Now, consistency index (CI) can be calculated as follows:

$$
\mathrm{CI}=\frac{\lambda \max -\mathrm{n}}{\mathrm{n}-1}
$$

where $\mathrm{CI}$ denotes the consistency index, $\mathrm{n}$ indicates the number of factors used for the comparison in the matrix, and $\lambda_{\max }$ is the highest or principal eigenvalue of the matrix. If the consistency index does not meet a certain threshold, the comparison results are re-examined.

The consistency judgment must be checked by CR for the appropriate value of $n$ to ensure the consistency of the pairwise comparison matrix. The CR coefficients are 
computed using Saaty's methodology. CR coefficients of less than 0.1 indicate the pairwise comparison matrix's overall consistency [60,62-64].

$$
\mathrm{CR}=\frac{\mathrm{CI}}{\mathrm{RI}}
$$

where RI indicates the average of the consistency index calculated as a result of the matrix [62]. Table 6 shows the RI values for various values of $n$.

More consistency is indicated by a lower CR ratio. If CR is greater than 0.10 , inconsistencies can be seen in the matrix's weight values. In this case, the AHP may not produce useful findings unless the judgments are re-examined, and changes are necessary to reduce the inconsistency to less than $0.10 .[57,63,65]$.

\subsection{Weighted Overlay Analysis for Land Suitability}

The reclassified all raster data which were classified based on their suitability level were then put in the weighted overlay process. Once the weight of each criterion was determined through the AHP process, the weight was employed in the weight overlay process in the spatial analyst tool in ArcGIS. Finally, a Green gram suitability map was produced (Figure 7). All the reclassified raster data were projected in 1984 UTM Zone 46 $\mathrm{N}$ to achieve the same geographic extent. The calculation of the area in hectares and the percentage for each class was done for all suitability classes of the final suitability map and all reclassified maps.

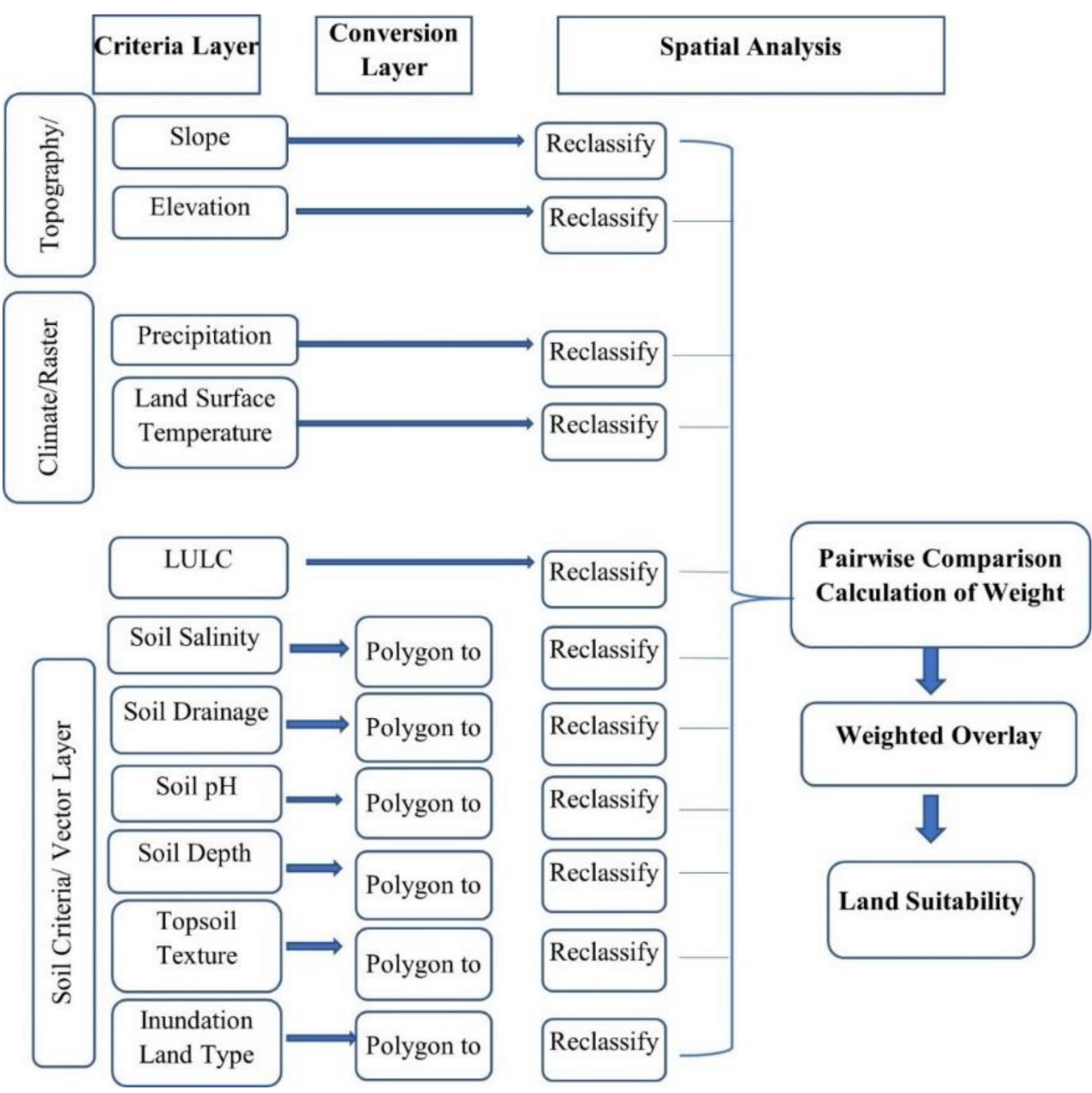

Figure 7. Conceptual framework of the land suitability analysis in ArcGIS. 


\subsection{Sensitivity Analysis}

The weights assigned to the various parameters would have a significant impact on overall goals. A "what-if" strategy can be used to see how the final results might have altered if the parameter weights were different. Sensitivity analysis is the term for this procedure. Sensitivity analysis helps us figure out how solid our initial decision was and what factors affected it (i.e., what factors influenced the original outcomes). This is a vital step in the process, and no final decision can be taken without conducting a sensitivity study [61]. In this research, equal weights were assigned to each parameter in the weighted overlay process, and, accordingly, a suitability map was generated. This was done to check to what extent the areal and spatial distribution of each suitability class varied if the weight of the criteria were changed.

\section{Result}

\subsection{Reclassification}

The result of reclassification of the eleven criteria considered for green gram production are described by the four classes of suitability for each parameter. The determined proportional, areal (Table 7), and spatial distribution (Figure 8a-k) of the classified criteria are discussed below.

Table 7. Areal and proportional distribution of the criteria considered for pulse crop suitability in the coastal region of Bangladesh.

\begin{tabular}{|c|c|c|c|c|}
\hline \multirow{2}{*}{ Parameters } & \multirow{2}{*}{ Suitability Class } & \multirow{2}{*}{ Sub Criteria } & \multicolumn{2}{|c|}{ Area } \\
\hline & & & Ha & $\%$ \\
\hline \multirow{4}{*}{ Soil Texture } & S1 & Loam, silt loam & $2,665,248.5$ & 79.5 \\
\hline & S2 & Silty clay, silty clay Loam and clay & $40,852.2$ & 1.2 \\
\hline & S3 & Predominantly clay & $619,924.8$ & 18.5 \\
\hline & NS & Muck, peat, and sand & $28,282.2$ & 0.84 \\
\hline \multirow{4}{*}{$\begin{array}{l}\text { Soil Salinity } \\
(\mathrm{MMHOS} / \mathrm{cm})\end{array}$} & S1 & $<2$ & $2,272,581.7$ & 67.7 \\
\hline & $\mathrm{S} 2$ & $2-4$ & $466,943.4$ & 13.9 \\
\hline & S3 & $4-8$ & $573,216.3$ & 17.1 \\
\hline & NS & $8-15$ & $41,566.4$ & 1.2 \\
\hline \multirow{4}{*}{ Soil Drainage } & S1 & Well drained & $276,823.6$ & 8.3 \\
\hline & S2 & Moderately drained & $505,938.7$ & 15.1 \\
\hline & S3 & Poorly drained & $2,419,992.5$ & 72.1 \\
\hline & NS & Very poorly drained & $151,553.1$ & 4.5 \\
\hline \multirow{4}{*}{ Soil pH } & $\mathrm{S} 1$ & $5.5-7.3$ & $1,669,797.7$ & 49.8 \\
\hline & S2 & $7.3-8.4$ & $291,821.8$ & 8.7 \\
\hline & S3 & $7.3-8.4 / 4.5-5.5 /<4.5$ & $1,357,978.3$ & 40.5 \\
\hline & NS & $>8.5 \&<4.5$ & $3,4710.1$ & 1.03 \\
\hline \multirow{4}{*}{ Soil Depth (m) } & S1 & $>1.22$ & $2,027,754.3$ & 60.5 \\
\hline & $\mathrm{S} 2$ & $0.90-1.22$ & $1,285,129.9$ & 38.3 \\
\hline & S3 & $0.25-0.090$ & $33,853.04$ & 1.0 \\
\hline & NS & $<0.25$ & 7570.5 & 0.22 \\
\hline \multirow{4}{*}{ Inundation Land Type } & $\mathrm{S} 1$ & Highland/Medium highland & $2,572,863.6$ & 80.5 \\
\hline & S2 & Medium lowland & $469,013.8$ & 14.7 \\
\hline & S3 & Lowland & $127,821.9$ & 3.9 \\
\hline & NS & Very lowland & $28,135.1$ & 0.9 \\
\hline \multirow{4}{*}{ Rainfall (mm) } & S1 & $1069-1500$ & $1,632,552.6$ & 45.2 \\
\hline & $\mathrm{S} 2$ & $1500-1600$ & $364,185.9$ & 10.1 \\
\hline & S3 & $1600-1800$ & $715,803.8$ & 19.8 \\
\hline & NS & $1800-2360$ & $899,467.7$ & 24.9 \\
\hline \multirow{4}{*}{$\begin{array}{c}\text { Land Surface } \\
\text { Temperature (LST) }\left({ }^{\circ} \mathrm{C}\right)\end{array}$} & S1 & $26-30$ & $3,049,495.2$ & 85.3 \\
\hline & S2 & $25-26$ & $451,089.3$ & 12.6 \\
\hline & S3 & $23.2-25$ & $64,849.4$ & 1.8 \\
\hline & NS & $30-31.8$ & 8856.1 & 0.25 \\
\hline
\end{tabular}


Table 7. Cont

\begin{tabular}{|c|c|c|c|c|}
\hline \multirow{2}{*}{ Parameters } & \multirow{2}{*}{ Suitability Class } & \multirow{2}{*}{ Sub Criteria } & \multicolumn{2}{|c|}{ Area } \\
\hline & & & $\mathrm{Ha}$ & $\%$ \\
\hline \multirow{4}{*}{ Land Use Land Cover } & S1 & Agricultural land & $1,103,260.9$ & 28.4 \\
\hline & S2 & Fallow/Bare land & $759,741.7$ & 19.6 \\
\hline & S3 & Forest vegetation & $1,362,364.4$ & 35.1 \\
\hline & NS & Water/Urban & $652,900.8$ & 16.8 \\
\hline \multirow{4}{*}{ Slope (\%) } & S1 & 00-10 & $3,723,847.6$ & 96.1 \\
\hline & S2 & $10-20$ & $117,838.7$ & 3.04 \\
\hline & S3 & $20-30$ & $23,567.7$ & 0.6 \\
\hline & NS & $30-77.4$ & 9998.4 & 0.3 \\
\hline \multirow{4}{*}{ Elevation (m) } & S1 & $00-50$ & $3,821,975.1$ & 98.5 \\
\hline & S2 & $50-100$ & $41,279.2$ & 1.1 \\
\hline & S3 & $100-200$ & $11,426.8$ & 0.3 \\
\hline & NS & $200-255$ & 571.4 & 0.1 \\
\hline
\end{tabular}

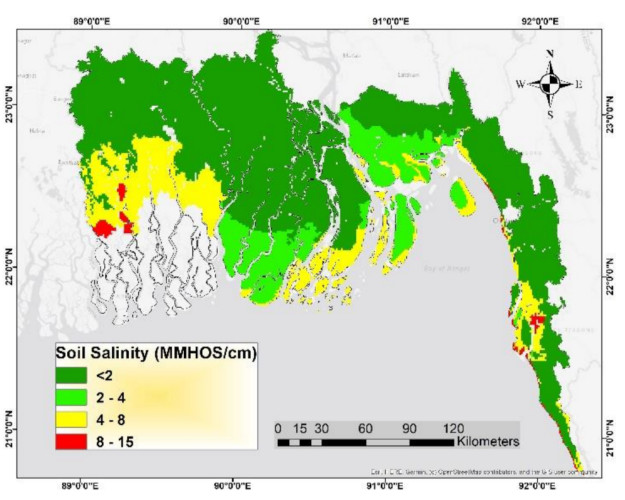

(a)

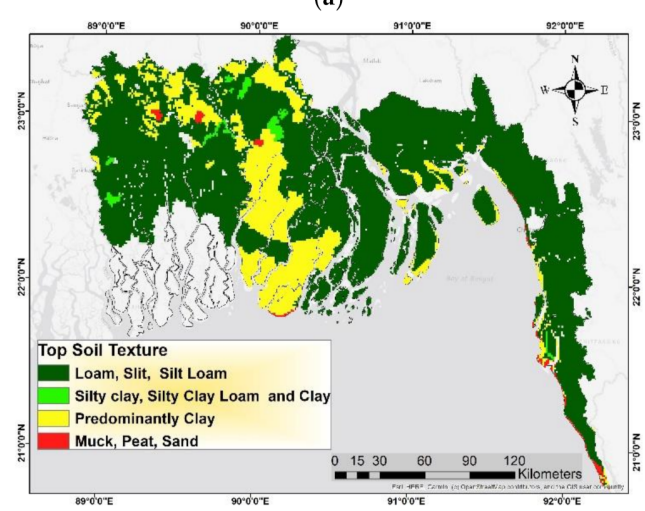

(c)

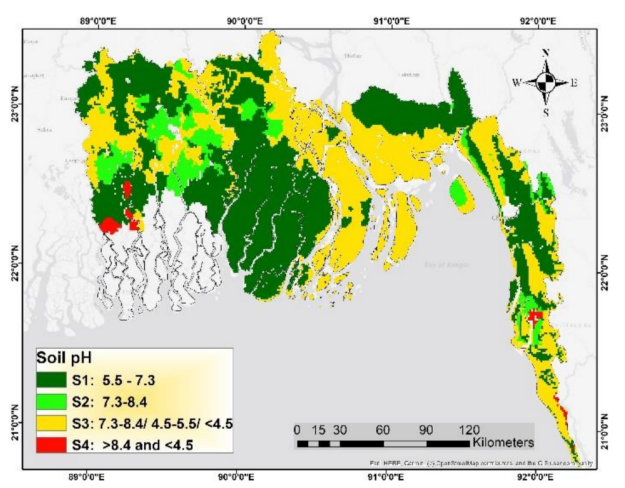

(e)

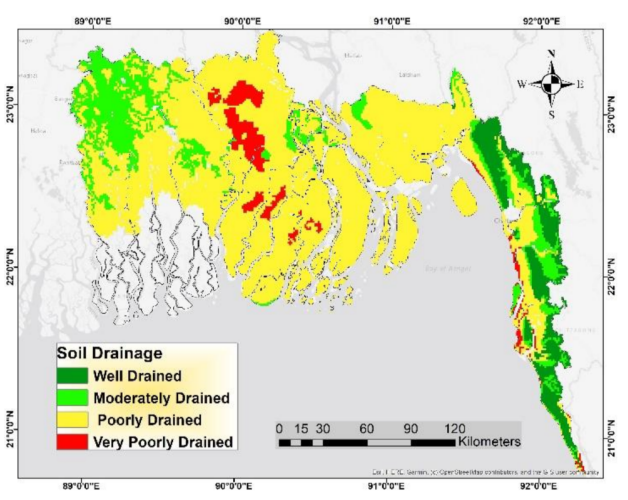

(b)

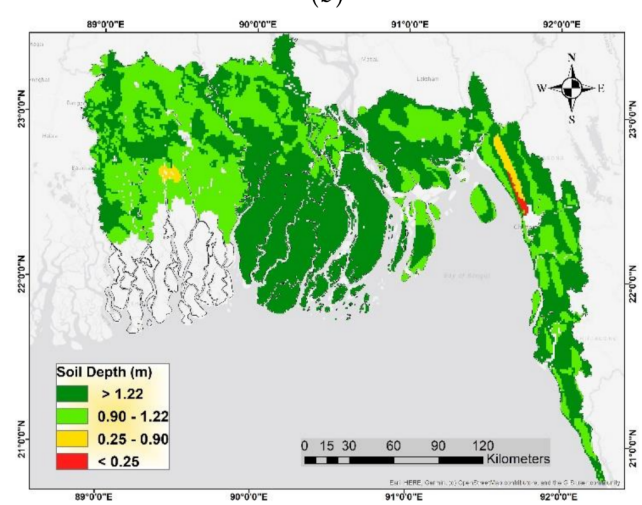

(d)

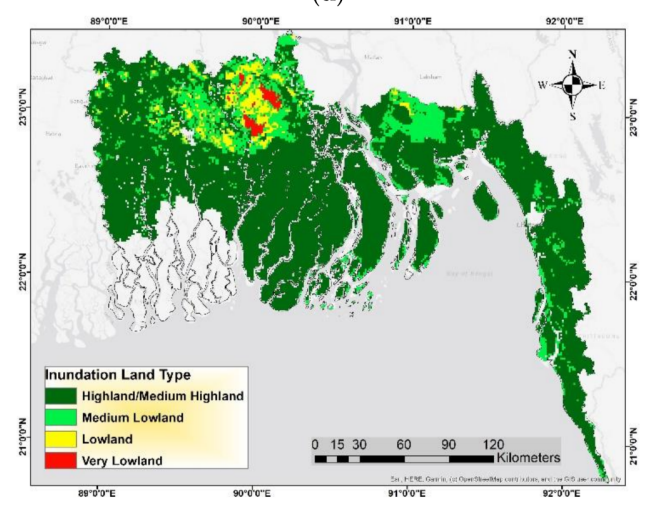

(f)

Figure 8. Cont. 


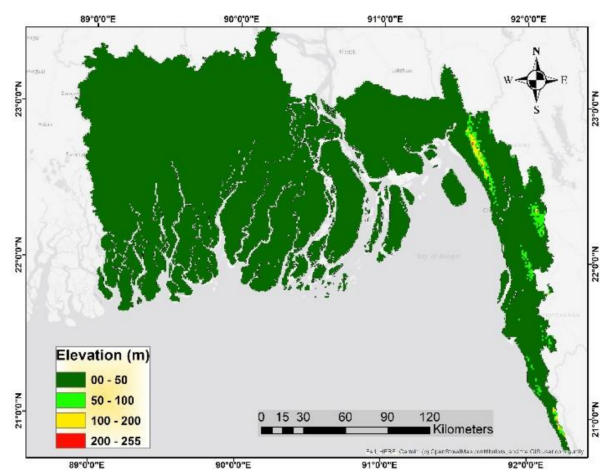

(g)

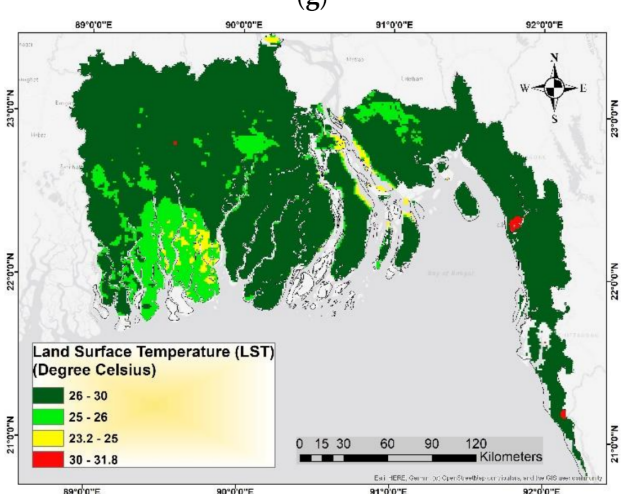

(i)

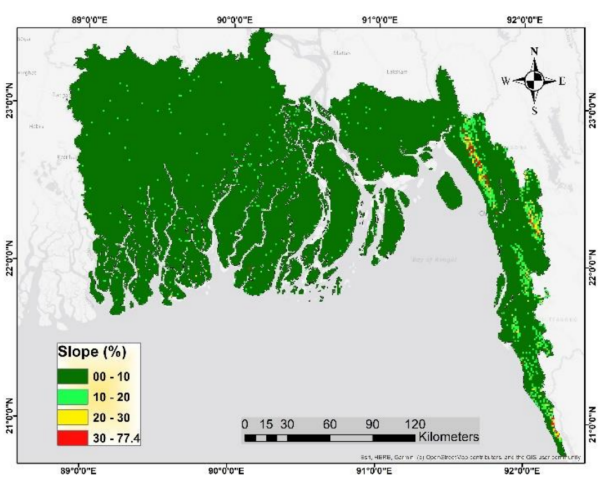

(h)

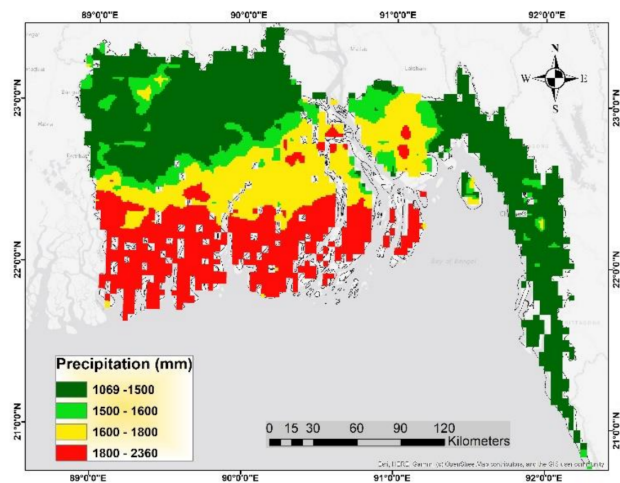

(j)

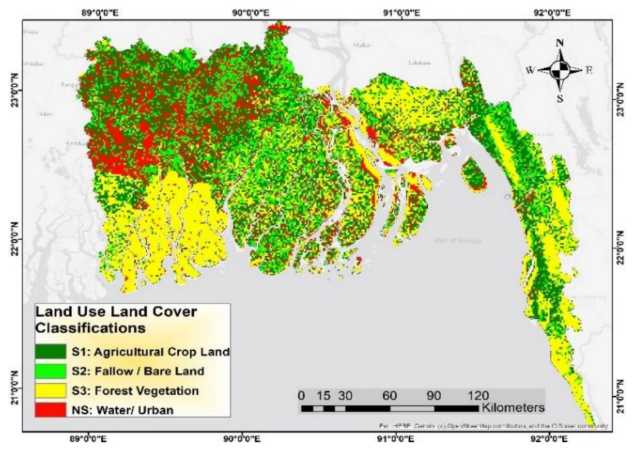

(k)

Figure 8. Spatial distribution of reclassified criteria (a) Soil Salinity; (b) Soil Drainage; (c) Topsoil Texture; (d) Soil Depth; (e) Soil pH; (f) Inundation Land Type; (g) Elevation; (h) Slope; (i) Land Surface Temperature (LST); (j) Precipitation; (k) Land Use Land Cover (LULC).

The reclassification result for the soil salinity criteria indicates that 67.8 percent of the study area is found to have no saline soil, which is highly suitable for agricultural crop production, including mung bean, while only $1.2 \%$ of the land area is not suitable. As much as $13.9 \%$ and $17.1 \%$ of the coastal area have a slightly saline and a moderately saline soil, respectively. From Figure 8a, it is found that the salt concentration is very high in the southwest coastal site.

In terms of soil drainage, Table 7 shows that soil drainage conditions are unfortunately very poor in the majority of the area. More than $72 \%$ of the area has a poorly drained soil, whereas only $8.3 \%$ of the area is found to have a well-drained soil, which is indicated as a highly suitable area. Only the eastern part of the study area showed a well-drained soil, while the western area showed a very poorly drained soil (Figure $8 \mathrm{~b}$ ).

The majority of the coastal area (79.5\%) soil is in the loam, silt, and silt loam category, considering the highly suitable area, whilst $18.5 \%$ of the area is predominantly clay soil, which is marginally suitable for plant growth. Only $1.2 \%$ of the area belongs to the silty clay loam, and the silty clay class ranked second in terms of good textured soil. Few areas 
with muck, peat, and sandy soil were found. It is observed that $60.5 \%$ of the land area has a deep soil (highly suitable), while $38.3 \%$ of the land is considered to be moderately deep. Around half of the land contains a slightly acidic to slightly alkaline soil, with a $\mathrm{pH}$ ranging from 5.5 to 7.3 , which is regarded as highly suitable, while $40 \%$ of the soil is moderately suitable soil—slight to moderately to highly acidic or alkaline. The results of the land inundation parameter indicate that around $80 \%$ of the land area is highly suitable-high land to medium high land-and the remaining area is found to be medium low land to low land-moderately to marginally suitable.

For topographical criteria such as slope and elevation, it is very fortunate that more than $96 \%$ of the land area is highly suitable; only a few areas belong to the moderately, marginal, or not suitable area. In terms of climatic factors, the results of the Land Surface Temperature (LST) reclassification show that the majority of the area $(85.3 \%)$ has an annual mean temperature of 26-30 degrees Celsius, and is thus highly suitable for green gram cultivation, while $12.6 \%$ of the area is moderately suitable, with an annual mean LST of 25-26 degrees Celsius (Table 7, Figure 8i). From Figure 8j, it is observed that the annual mean rainfall is higher $(>1800 \mathrm{~mm})$ near the seashore, which is considered a marginally and not suitable area. As much as $45.2 \%$ of the area is found to be highly suitable (1069-1500 mm rainfall) for crop cultivation (Table 7).

Land Use Land Cover determines the particular land area that is occupied by a particular component, such as vegetation, crop, buildings, and so on. Most vegetation areas are highly suitable for any kind of crop production, while urban areas are not suitable. The land use land cover classification shows that around $28 \%$ of the total land area is considered agricultural land (highly suitable), and $19.6 \%$ of the land is moderately suitable (fallow /bare land). Forests and built-up areas (not suitable areas) cover $35.1 \%$ and $16.8 \%$ of the land area, respectively (Table 7).

\subsection{AHP}

In the AHP analysis, we calculated the weight of the 11 criteria to determine the relative importance (priority) of the criteria, which influences the final decision process of green gram suitability. Accordingly, the criteria were also ranked based on the estimated weight. From the AHP result, it is found that soil salinity has the highest contribution $(29 \%)$, while slope, elevation, and LULC have the lowest contribution $(2 \%)$ to the final decision process. From Table 8, it is observed that the criteria are ranked according to the weight. Soil salinity ranked first, soil drainage ranked second, soil $\mathrm{pH}$ ranked third, soil texture ranked fourth, soil depth ranked fifth, and inundation land type, rainfall, and LST ranked sixth, seventh, and eighth, respectively. LULC, elevation, and slope have the same rank (ninth position). Our judgments and preferences determine the priority of the factors rather than being assigned arbitrarily. These priorities are both mathematically correct and intuitively interpretable as measurement values produced from a ratio scale.

Table 8. Results of the AHP analysis of the land suitability of green gram production.

\begin{tabular}{ccc}
\hline Parameters & Priority & Rank \\
\hline Soil salinity & 0.29 & 1 \\
Soil drainage & 0.19 & 2 \\
Soil pH & 0.14 & 3 \\
Soil texture & 0.11 & 4 \\
Soil depth & 0.09 & 5 \\
Inundation type & 0.05 & 6 \\
Rainfall & 0.04 & 7 \\
Land Surface Temperature (LST) & 0.03 & 8 \\
Land Use Land Cover (LULC) & 0.02 & 9 \\
Elevation & 0.02 & 9 \\
Slope & 0.02 & 9 \\
\hline
\end{tabular}

Maximum Eigen value $(\lambda \max )=11.09, \mathrm{n}=11$, Consistency Index $(\mathrm{CI})=(\lambda \max -\mathrm{n}) /(\mathrm{n}-1)=0.009$, Random Index $(\mathrm{RI})=1.51$, Consistency Ratio $(\mathrm{CR})=\mathrm{CI} / \mathrm{RI}=0.006$. 


\subsection{Final Green Gram Suitability Map}

The final green gram suitability map was produced through the weighted overlay process, and the weights of the criteria were utilized. In the statistical analysis of the final land suitability classification, it is found that the majority of the land area, $82.3 \%$ of the coastal region $(2,282,800.5 \mathrm{ha})$, belongs to the moderately suitable land for pulse crop (green gram) production, while only $12.4 \%$ of the total study area with the $344,619.5$-ha area is determined as highly suitable land for green gram crop production. More than $5 \%$ of the total area $(144,246.0 \mathrm{ha})$ is estimated as marginally suitable, and a small part of the area (less than 1\%) is considered as not suitable land (Table 9). In terms of spatial distribution, it is observed that highly suitable lands are confined mostly to the easternmost part of the country, while the largest portion of marginally suitable lands is in the southwestern region (Figure 9a). From the studies, it can be inferred that the land is less suitable when closer to the sea, the Bay of Bengal, which is caused by the cumulative effect of climate change. On the other hand, the lands that are far from the coast are more suitable for agriculture.

Table 9. Area and percentage of green gram suitability.

\begin{tabular}{ccccc}
\hline \multirow{2}{*}{$\begin{array}{c}c \\
\text { Cand Suitability }\end{array}$ Lassification } & Area (ha) & Percentage Area (\%) & \multicolumn{2}{c}{ Land Suitability with Equal Weight } \\
\cline { 2 - 5 } & $344,619.5$ & 12.4 & $91,546.2$ & Percentage Area (\%) \\
\hline Highly Suitable (S1) & $2,282,800.5$ & 82.3 & $1,869,628.5$ & 3.3 \\
Moderately Suitable (S2) & $144,246.0$ & 5.2 & $778,642.9$ & 67.4 \\
Marginally Suitable (S3) & 2285.1 & 0.1 & $34,133.5$ & 28.1 \\
Not Suitable (S4) & $2,773,951$ & 100 & $2,773,951$ & 1.2 \\
Total & & & 100 \\
\hline
\end{tabular}

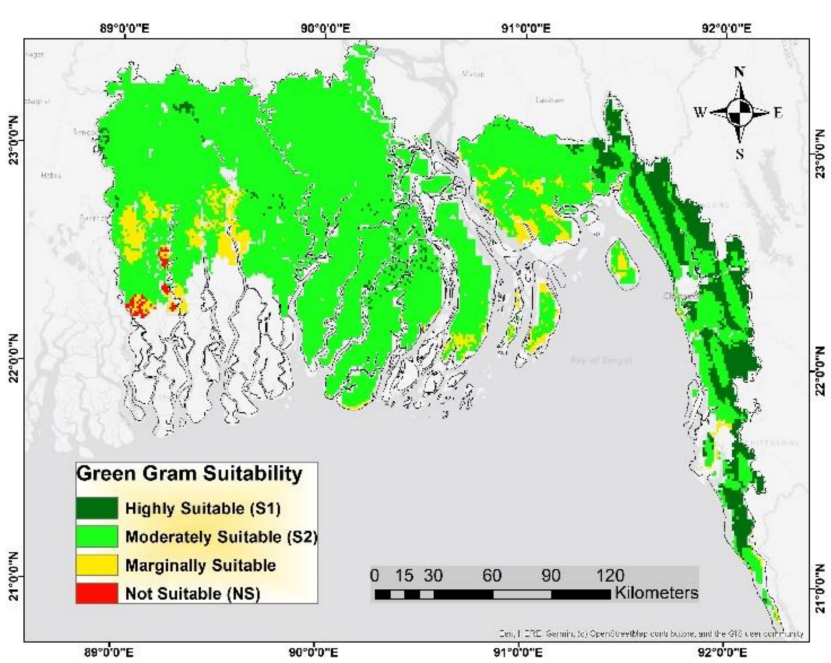

(a)

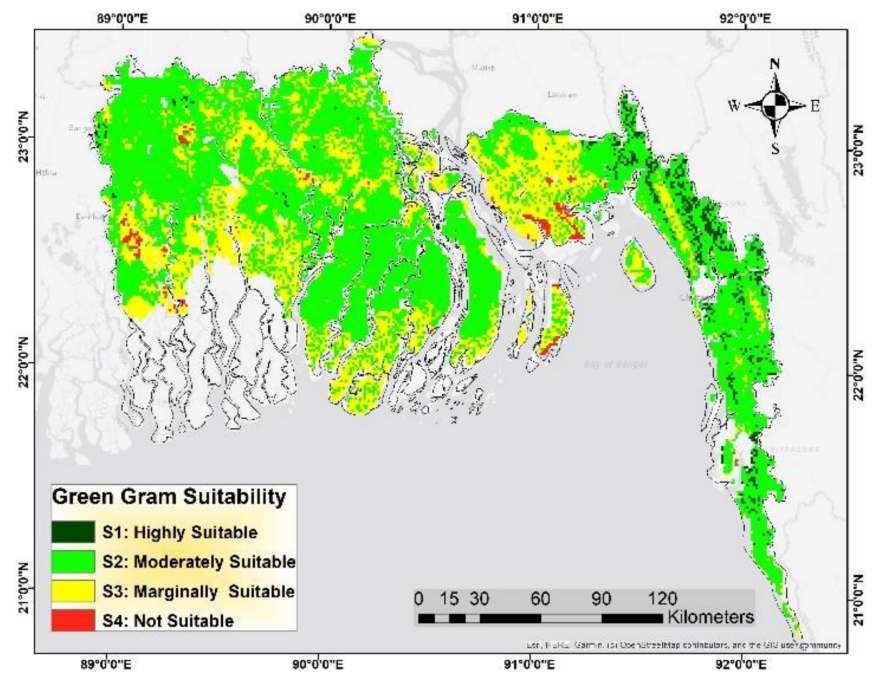

(b)

Figure 9. Spatial distribution of results: (a) Final green gram suitability map; (b) Green gram suitability map (sensitivity analysis).

\subsection{Sensitivity Analysis}

The sensitivity analysis, which is carried out using equal weights for all criteria, produced a significantly different result in suitability at a different level. It is estimated that $3.3 \%$ of the land $(91,546.2$ ha) is highly suitable, while the majority of land $-67.4 \%$ of the area, with $1,869,628.5$ hectares-is found to be moderately suitable for green gram cultivation. In addition, $778,642.9$ hectares of land (28.1\%) belong to the marginally suitable category, and $1.2 \%$ of the land area is not in the suitable class (Table 9 and Figure $9 \mathrm{~b}$ ). 


\section{Discussion}

This study examined the suitable land for pulse (green gram) production in coastal Bangladesh, and this section will describe the suitable land area with some important criteria based on the study results.

The suitability level of each reclassified criteria significantly affects in the final green gram suitability. Soil salinity, soil drainage, soil $\mathrm{pH}$, and topsoil texture are important criteria among them. In terms of soil salinity, it is found that the salt concentration is very high in the southwestern coastal site. The land area, which is very close to the coast, is highly affected by soil salinity. This is due to the fact that natural disasters enhance this salinity intrusion. The salt concentration in the soil might impair the nutrient uptake by the plant and eventually deter the growth and development of the plant. Salinity is expected to reduce crop production in up to $20 \%$ of irrigated lands around the world, and this loss will rise to about $50 \%$ of arable land by the mid-twentieth century [66]. Several studies have recently shown that soil salinity stress reduces the physiological attributes of crops like mung bean (Vigna radiata L.) [67]. Hence, an increase in soil salinity implies a decrease in the suitability for crop production.

Soil drainage conditions directly affect the growth and development of crop plants. Agricultural soils need good drainage conditions to increase agricultural crop production by maintaining the water sources [68]. This plays a key role in aeration in the root system, affecting crop growth. The majority of the study area is not well-drained soil, and is thus highly prone to water stagnation, which inhibits green gram cultivation.

Soil texture is a physical property and a significant factor in crop development and field management [69]. The coastal area of Bangladesh contains predominantly loam, silt, and silt loam soil, which is a very favorable soil condition for any kind of plant production, including green gram. Few areas in the eastern part contain muck and peat soil, and green gram cannot be produced in that kind of soil.

Soil depth also has a significant effect on green gram cultivation. Root penetration may be physically limited by any discontinuities in the soil profile, from sand or gravel layers to bedrock. When using irrigation, it can also cause issues. To grow and increase physical fertility, soil macro- and mesobiota need sufficient soil [70]. Most of the coastal area is found to contain well-depth soils.

In the case of soil $\mathrm{pH}$, alkaline soil is found at almost every corner of the study area, which is not a favorable condition for green gram production. The middle part of the study area, including the Barishal region, contains predominantly alkaline soils, with a $\mathrm{pH}$ value greater than 7. Soil $\mathrm{pH}$ is one of the most important factors affecting the plants absorption of trace elements, with a higher soil $\mathrm{pH}$ resulting in higher adsorption (and thus lower availability) [71-74]. High land (HL), medium high land (MHL), medium low land (MLL), low land (LL), and very low land (VLL) are the five inundation landforms in Bangladesh [75]. The majority of the study area is covered with high land to medium high land. Low land and very low land are highly vulnerable to floods, which leads to significant crop losses.

As regards the topography, the slope is considered as the most important parameter for land suitability studies for agricultural crops in all areas. Usually, slope contributes indirectly to crop cultivation. When it comes to mechanization, slope, an integral feature of landform, plays a significant role. The only land with a slope of less than 8 degrees should be used, according to Navas and Machin [76], to prevent soil erosion and other problems associated with the use of machinery. Green gram is highly suitable at a slope of $0-10$ percent, moderately suitable at $11-20$ percent, slightly suitable at $21-35$ percent, and not suitable at slopes above that percentage, according to Grealish et al. [77], in an Australian analysis on the soils and land suitability of agricultural growth areas.

Generally, higher elevations are less suitable for mung bean production, and vice versa. Green gram grows best at the height of 0-1600 $\mathrm{m}$ above the sea level [78], with a maximum elevation of $2000 \mathrm{~m}[78,79]$. Higher annual mean rainfall is found in the seashore line, while a comparatively lower rainfall, considered a favorable condition, is observed 
mostly in areas distant from the coastline. A suitable land surface temperature is observed in almost all parts of the study area. Mung bean (green gram) is a warm-season crop, which can be cultivated in temperatures between 20 and 40 degrees Celsius [80]. However, seed germination and plant growth are best at temperatures between 28 and 300 degrees Celsius [80-82].

From the final green gram suitability map, it is found that only 12 percent of the land area is highly suitable for green gram production. This is due to the fact that a significant land area is affected by soil salinity, and the majority of the area contains a poorly drained soil. These two parameters have a remarkable impact on the decisionmaking process. According to the AHP analysis (weighted overlay process in ArcGIS), the weight of their was 29\% and 19\%, respectively. From the spatial distribution point of view, it is found that the highly suitable area belongs mostly to the eastern part of the country. This spatial distribution of highly suitable land also coincides with the spatial distribution of the "agricultural crop land" class in the land use land cover map, where agricultural cropland is found above all in the eastern part of the country. Additionally, from the above discussion, it can be concluded that the eastern part of the study area is highly suitable in terms of all criteria considered, when compared to other parts of the area. The impact of the weights of the criteria can be measured by the sensitivity analysis and consequently provide a validation of the GIS-based multicriteria decision-making model. In sensitivity analysis, when the weight is changed for the criteria, the final suitability results also change. The areas with different levels of suitability are significantly altered when equal weights are assigned to each parameter.

\section{Conclusions}

In order to ensure the food security of the coastal region of Bangladesh, a land evaluation system is required to find out the potential land area for the cultivation of a specific crop. This study was carried out to find out the best potential land for pulse (green gram) crop cultivation in the coastal region of Bangladesh. The study used GIS and remote sensing with multicriteria analysis while considering 11 parameters associated with topography, climate, and soil. The study identified soil salinity as a major problem or constraint for pulse production, with the highest importance (30\%). Another important parameter is soil drainage, with a weight of $19 \%$, causing a decrease of the area belonging to the highly suitable class. In the final assessment, it is found that only $8.36 \%$ of the study area is highly suitable (S1) land, while the largest area, representing $74 \%$ of the land, is moderately suitable (S2). Along with a higher weight value, a poor soil drainage condition covering more than $73 \%$ of the land results in less land area in the highly suitable (S1) class in the final suitability map. Additionally, it is observed that the highly suitable (S1) land area belongs mostly to the southeastern part of the country.

The results of this study can be of great importance for policymakers of the agriculture ministry of Bangladesh, as they will help them formulate and implement the necessary policies to optimize pulse production. The government should prioritize the southern part-Chittagong, Cox's Bazar, and Noakhali districts, for example-to enhance green gram cultivation by providing incentives such as seed, fertilizer, etc., to the farmers, and avoid the peripheral coastal area. In addition, the government, donor agencies, and NGOs need to implement strategies to reduce soil salinity and improve soil drainage to improve pulse production. This study can be used as a model for land evaluation in many other agricultural crops in the country and abroad.

Author Contributions: Conceptualization, B.H. and H.Y.; methodology, B.H., H.Y. and T.M.; validation, B.H., H.Y. and T.M.; formal analysis, B.H., H.Y. and T.M.; investigation, B.H. and H.Y.; resources, B.H.; data curation, B.H.; writing-original draft preparation, B.H.; writing-review and editing, H.Y.; supervision, H.Y. and T.M. All authors have read and agreed to the published version of the manuscript.

Funding: No external funding was obtained for this research. 
Data Availability Statement: All data are reported in this work.

Conflicts of Interest: The authors declare no conflict of interest.

\section{Appendix A. Model Builder for Suitability Analysis in ArcGIS}

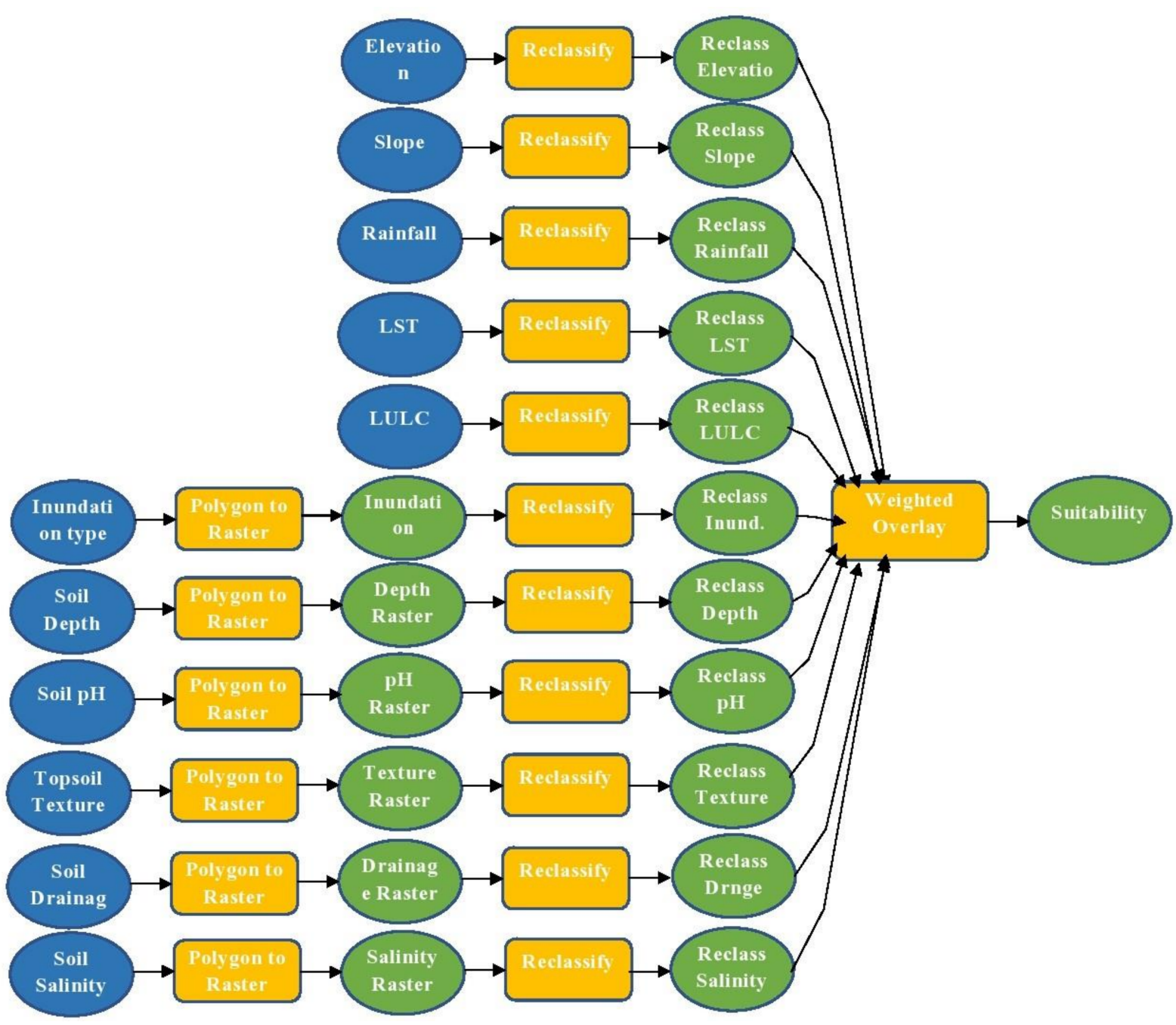

\section{References}

1. Karim, N. Disasters in Bangladesh. Nat. Hazards 1995, 11, 247-258. [CrossRef]

2. Hossain, M.N. Analysis of Human Vulnerability to Cyclones and Storm Surges Based on Influencing Physical and Socioeconomic Factors: Evidences from Coastal Bangladesh. Int. J. Disaster Risk Reduct. 2015, 13, 66-75. [CrossRef]

3. Harmeling, S. Global Climate Risk Index 2012: Who Suffer Most from Extreme Weather Events? Weather-Related Loss Events in 2010 and 1991 to 2010; Germanwatch: Bonn, Germany, 2011.

4. Sattar, M.A.; Cheung, K.K.W. Tropical Cyclone Risk Perception and Risk Reduction Analysis for Coastal Bangladesh: Household and Expert Perspectives. Int. J. Disaster Risk Reduct. 2019, 41, 101283. [CrossRef]

5. Hossain, M.A.; Reza, M.I.; Rahman, S.; Kayes, I. Climate change and its impacts on the livelihoods of the vulnerable people in the southwestern coastal zone in Bangladesh. In Climate Change and the Sustainable Use of Water Resources; Springer: Berlin/Heidelberg, Germany, 2012; pp. 237-259.

6. Rawlani, A.K.; Sovacool, B.K. Building Responsiveness to Climate Change through Community Based Adaptation in Bangladesh. Mitig. Adapt. Strateg. Glob. Chang. 2011, 16, 845-863. [CrossRef]

7. Kumar, L.; Taylor, S. Exposure of Coastal Built Assets in the South Pacific to Climate Risks. Nat. Clim. Chang. 2015, 5, 992-996. [CrossRef]

8. Paice, R.; Chambers, J. Climate Change Impacts on Coastal Ecosystems; National Climate Change Adaptation Research Facility: Gold Coast, Australia, 2016. 
9. Moser, S.C.; Davidson, M.A.; Kirshen, P.; Mulvaney, P.; Murley, J.F.; Neumann, J.E.; Petes, L.; Reed, D. Coastal Zone Development and Ecosystems. In Climate Change Impacts in the United States: The Third National Climate Assessment; U.S. Global Change Research Program: Washington, DC, USA, 2014; pp. 579-618. [CrossRef]

10. Lambin, E.F.; Coomes, O.T.; Turner, B.L.; Geist, H.J.; Agbola, S.B.; Angelsen, A.; Folke, C.; Bruce, J.W.; Coomes, O.T.; Dirzo, R.; et al. The Causes of Land-Use and Land-Cover Change: Moving beyond the Myths. Glob. Environ. Chang. 2001, 11, 261-269. [CrossRef]

11. Stuart, D. Coastal Ecosystems and Agricultural Land Use: New Challenges on California's Central Coast. Coast. Manag. 2010, 38, 42-64. [CrossRef]

12. Dahiya, P.K.; Linnemann, A.R.; Van Boekel, M.A.J.S.; Khetarpaul, N.; Grewal, R.B.; Nout, M.J.R. Mung Bean: Technological and Nutritional Potential. Crit. Rev. Food Sci. Nutr. 2015, 55, 670-688. [CrossRef]

13. Hou, D.; Yousaf, L.; Xue, Y.; Hu, J.; Wu, J.; Hu, X.; Feng, N.; Shen, Q. Mung Bean (Vigna radiata L.): Bioactive Polyphenols, Polysaccharides, Peptides, and Health Benefits. Nutrients 2019, 11, 1238. [CrossRef]

14. Di Paola, A.; Rulli, M.C.; Santini, M. Human Food vs. Animal Feed Debate. A Thorough Analysis of Environmental Footprints. Land Use Policy 2017, 67, 652-659. [CrossRef]

15. Field Services Wing (FSW); Department of Agricultural Extension (DAE), Ministry of Agriculture: Dhaka, Bangladesh, 2021.

16. Overview of Mung Bean Import to Bangladesh, 2021, Tridge. Available online: https://www.tridge.com/intelligences/mungbean/BD/import (accessed on 5 May 2021).

17. Borie, C.; Parcero-Oubiña, C.; Kwon, Y.; Salazar, D.; Flores, C.; Olguín, L.; Andrade, P. Beyond Site Detection: The Role of Satellite Remote Sensing in Analysing Archaeological Problems. A Case Study in Lithic Resource Procurement in the Atacama Desert, Northern Chile. Remote Sens. 2019, 11, 869. [CrossRef]

18. Demarez, V.; Helen, F.; Marais-Sicre, C.; Baup, F. In-Season Mapping of Irrigated Crops Using Landsat 8 and Sentinel-1 Time Series. Remote Sens. 2019, 11, 118. [CrossRef]

19. Zhou, T.; Pan, J.; Zhang, P.; Wei, S.; Han, T. Mapping Winter Wheat with Multi-Temporal SAR and Optical Images in an Urban Agricultural Region. Sensors 2017, 17, 1210. [CrossRef] [PubMed]

20. Dong, J.; Xiao, X.; Kou, W.; Qin, Y.; Zhang, G.; Li, L.; Jin, C.; Zhou, Y.; Wang, J.; Biradar, C.; et al. Tracking the Dynamics of Paddy Rice Planting Area in 1986-2010 through Time Series Landsat Images and Phenology-Based Algorithms. Remote Sens. Environ. 2015, 160, 99-113. [CrossRef]

21. Kussul, N.; Lemoine, G.; Gallego, F.J.; Skakun, S.V.; Lavreniuk, M.; Shelestov, A.Y. Parcel-Based Crop Classification in Ukraine Using Landsat-8 Data and Sentinel-1A Data. IEEE J. Sel. Top. Appl. Earth Obs. Remote Sens. 2016, 9, 2500-2508. [CrossRef]

22. Bandyopadhyay, S.; Jaiswal, R.K.; Hegde, V.S.; Jayaraman, V. Assessment of Land Suitability Potentials for Agriculture Using a Remote Sensing and GIS Based Approach. Int. J. Remote Sens. 2009, 30, 879-895. [CrossRef]

23. Purnamasari, R.A.; Ahamed, T.; Noguchi, R. Land Suitability Assessment for Cassava Production in Indonesia Using GIS, Remote Sensing and Multi-Criteria Analysis. Asia-Pac. J. Reg. Sci. 2019, 3, 1-32. [CrossRef]

24. Islam, M.M.; Ahamed, T.; Noguchi, R. Land Suitability and Insurance Premiums: A GIS-Based Multicriteria Analysis Approach for Sustainable Rice Production. Sustainability 2018, 10, 1759. [CrossRef]

25. Pandey, V.; Srivastava, P.K. Integration of Microwave and Optical/Infrared Derived Datasets for a Drought Hazard Inventory in a Sub-Tropical Region of India. Remote Sens. 2019, 11, 439. [CrossRef]

26. Liu, J.; Xu, Z.; Chen, F.; Chen, F.; Zhang, L. Flood Hazard Mapping and Assessment on the Angkor World Heritage Site, Cambodia. Remote Sens. 2019, 11, 98. [CrossRef]

27. Silva, C.; Ferreira, J.G.; Bricker, S.B.; DelValls, T.A.; Martín-Díaz, M.L.; Yáñez, E. Site Selection for Shellfish Aquaculture by Means of GIS and Farm-Scale Models, with an Emphasis on Data-Poor Environments. Aquaculture 2011, 318, 444-457. [CrossRef]

28. Muhsin, N.; Ahamed, T.; Noguchi, R. GIS-Based Multi-Criteria Analysis Modeling Used to Locate Suitable Sites for Industries in Suburban Areas in Bangladesh to Ensure the Sustainability of Agricultural Lands. Asia-Pac. J. Reg. Sci. 2018, 2, 35-64. [CrossRef]

29. Akther, A.; Ahamed, T.; Takigawa, T.; Noguchi, R. GIS-Based Multi-Criteria Analysis for Urban Waste Management. J. Jpn. Inst. Energy 2016, 95, 457-467. [CrossRef]

30. Halder, J.C. Land Suitability Assessment for Crop Cultivation by Using Remote Sensing and GIS. J. Geogr. Geol. 2013, 5, 65-74. [CrossRef]

31. Lupia, D.F. Crop/Land Suitability Analysis by ArcGIS Tools; Technical report; CREA Research Centre for Agricultural Policies and Bioeconomy: Rome, Italy, 2014.

32. Joerin, F.; Thérialult, M.; Musy, A. Using GIS and Outranking Multicriteia Analysis for Land-Use Suitability Assesment. Int. J. Geogr. Inf. Sci. 2001, 15, 153-174. [CrossRef]

33. Li, L.; Zhao, J.; Yuan, T.; Liu, Z. Study on Approaches of Land Suitability Evaluation for Crop Production Using Geographic Information System. In Proceedings of the 7th World Congress on Computers in Agriculture Conference Proceedings, Reno, Nevada, 22-24 June 2009; WCCA 2009. pp. 289-294. [CrossRef]

34. Food and Agriculture Organization (FAO). A Framework for Land Evaluation; Food and Agriculture Organization of the United Nations, Soils Bulletin 32; FAO: Rome, Italy, 1976.

35. Bello-Dambatta, A.; Farmani, R.; Javadi, A.A.; Evans, B.M. The Analytical Hierarchy Process for Contaminated Land Management. Adv. Eng. Inform. 2009, 23, 433-441. [CrossRef]

36. Jafari, S.; Zaredar, N. Land Suitability Analysis Using Multi Attribute. Int. J. Environ. Sci. Dev. 2010, 1, 441-445. [CrossRef] 
37. Majumder, M. Impact of Urbanization on Water Shortage in Face of Climatic Aberrations; Springer: Singapore, 2015 ; pp. 35-47.

38. Bangladesh Bureau of Statistics (BBS). Yearbook of Agricultural Statistics of Bangladesh; Statistics Division, Ministry of Planning: Dhaka, Bangladesh, 2011.

39. Leighton, M.; Shen, X.; Warner, K. Climate Change and Migration: Rethinking Policies for Adaptation and Disaster Risk Reduction; United Nations University, Institute for Environment and Human Security (UNU-EHS): Druckerei Leppelt: Bonn, Germany, 2011.

40. Sys, C.; Ranst, E.; Debaveye, J. Land Evaluation Part I: Principles in Land Evaluation and Crop Production Calculations; General Administration for Development Cooperation: Brussels, Belgium, 1991.

41. Food and Agriculture Organization (FAO). Land Evaluation, Towards a Revised Framework; Land and Water Discussion Paper 6; Food and Agriculture Organization: Rome, Italy, 2007.

42. Akinci, H.; Özalp, A.Y.; Turgut, B. Agricultural Land Use Suitability Analysis Using GIS and AHP Technique. Comput. Electron. Agric. 2013, 97, 71-82. [CrossRef]

43. Mugo, J.W.; Kariuki, P.C.; Musembi, D.K. Identification of Suitable Land for Green Gram Production Using GIS Based Analytical Hierarchy Process in Kitui County, Kenya. J. Remote Sens. GIS 2016, 5, 17. [CrossRef]

44. Kumar, S. An Integrated Approach for Land Suitability Analysis for Agriculture through Remote Sensing and GIS-A Case Study of Seoni District (Madhya Pradesh), India. Int. J. Res. Appl. Sci. Eng. Technol. 2019, 7, 661-674. [CrossRef]

45. Habibie, M.I.; Noguchi, R.; Shusuke, M.; Ahamed, T. Land Suitability Analysis for Maize Production in Indonesia Using Satellite Remote Sensing and GIS-Based Multicriteria Decision Support System; Springer: Dordrecht, The Netherlands, 2021; Volume 86. [CrossRef]

46. Tashayo, B.; Honarbakhsh, A.; Akbari, M.; Eftekhari, M. Land Suitability Assessment for Maize Farming Using a GIS-AHP Method for a Semi- Arid Region, Iran. J. Saudi Soc. Agric. Sci. 2020, 19, 332-338. [CrossRef]

47. Mishra, A.K.; Deep, S.; Choudhary, A. Identification of Suitable Sites for Organic Farming Using AHP \& GIS. Egypt. J. Remote Sens. Sp. Sci. 2015, 18, 181-193. [CrossRef]

48. Bozdağ, A.; Yavuz, F.; Günay, A.S. AHP and GIS Based Land Suitability Analysis for Cihanbeyli (Turkey) County. Environ. Earth Sci. 2016, 75, 813. [CrossRef]

49. Karimi, F.; Sultana, S.; Shirzadi Babakan, A.; Royall, D. Land Suitability Evaluation for Organic Agriculture of Wheat Using GIS and Multicriteria Analysis. Pap. Appl. Geogr. 2018, 4, 326-342. [CrossRef]

50. Food and Agriculture Organization (FAO). Guidelines for Land-Use Planning; Food and Agriculture Organization of the United Nations: Rome, Italy, 1993.

51. Eastman, J.R.; Jiang, H.; Toledano, J. Multi-Criteria and Multi-Objective Decision Making for Land Allocation Using GIS. In Multicriteria Analysis for Land-Use Management; Springer: Dordrecht, The Netherlands, 1998; pp. 227-251. [CrossRef]

52. Saaty, T.L. How to Make a Decision: The Analytic Hierarchy Process. Eur. J. Oper. Res. 1990, 48, 9-26. [CrossRef]

53. Saaty, T.L. Fundamentals of Decision Making and Priority Theory with the Analytic Hierarchy Process; RWS publications: Pittsburgh, PA, USA, 2000; Volume 6.

54. Weerakoon, K. Suitability Analysis for Urban Agriculture Using GIS and Multi-Criteria Evaluation. Int. J. Agric. Sci. Technol. 2014, 2, 69. [CrossRef]

55. Triantaphyllou, E.; Mann, S.H. Using the analytic hierarchy process for decision making in engineering applications: Some challenges. Int. J. Ind. Eng. Theory Appl. Pract. 1995, 2, 35-44.

56. Kiker, G.A.; Bridges, T.S.; Varghese, A.; Seager, P.T.P.; Linkov, I. Application of Multicriteria Decision Analysis in Environmental Decision Making. Integr. Environ. Assess. Manag. 2005, 1, 95-108. [CrossRef] [PubMed]

57. Saaty, T.L. The Analytic Hierarchy Process; McGraw Hill: New York, NY, USA, 1980.

58. Rezaei-Moghaddam, K.; Karami, E. A Multiple Criteria Evaluation of Sustainable Agricultural Development Models Using AHP. Environ. Dev. Sustain. 2008, 10, 407-426. [CrossRef]

59. Mustafa, A.A.; Singh, M.; Sahoo, R.N.; Ahmed, N.; Khanna, M.; Sarangi, A. Land Suitability Analysis for Different Crops: A Multi Criteria Decision Making Approach Using Remote Sensing and GIS. Water Technol. 2011, 3, 61-84.

60. Mu, E.; Pereyra-Rojas, M. Understanding the Analytic Hierarchy Process. In Practical Decision Making; Springer: Cham, Switzerland, 2017; pp. 7-22. [CrossRef]

61. Saaty, T.L.; Vargas, L.G. Models, Methods, Concepts \& Applications of the Analytic Hierarchy Process; Springer: New York, NY, USA, 2012.

62. Ying, X.; Zeng, G.M.; Chen, G.Q.; Tang, L.; Wang, K.L.; Huang, D.Y. Combining AHP with GIS in Synthetic Evaluation of Eco-Environment Quality-A Case Study of Hunan Province, China. Ecol. Modell. 2007, 209, 97-109. [CrossRef]

63. Chen, Y.; Yu, J.; Khan, S. Spatial Sensitivity Analysis of Multi-Criteria Weights in GIS-Based Land Suitability Evaluation. Environ. Model. Softw. 2010, 25, 1582-1591. [CrossRef]

64. Park, S.; Jeon, S.; Kim, S.; Choi, C. Prediction and Comparison of Urban Growth by Land Suitability Index Mapping Using GIS and RS in South Korea. Landsc. Urban Plan. 2011, 99, 104-114. [CrossRef]

65. Chakraborty, S.; Banik, D. Design of a Material Handling Equipment Selection Model Using Analytic Hierarchy Process. Int. J. Adv. Manuf. Technol. 2006, 28, 1237-1245. [CrossRef]

66. Wang, W.; Vinocur, B.; Altman, A. Plant Responses to Drought, Salinity and Extreme Temperatures: Towards Genetic Engineering for Stress Tolerance. Planta 2003, 218, 1-14. [CrossRef]

67. Khan, M.I.R.; Asgher, M.; Khan, N.A. Alleviation of Salt-Induced Photosynthesis and Growth Inhibition by Salicylic Acid Involves Glycinebetaine and Ethylene in Mungbean (Vigna radiata L.). Plant Physiol. Biochem. 2014, 80, 67-74. [CrossRef] [PubMed] 
68. Haroun, O.R. Soil Evaluation Systems as a Guide to Identify an Economical Feasibility Study for Agricultural Purposes in El-Fayoum Province, Egypt. Ph.D. Thesis, Faculty of Agriculture, El-Fayoum Cairo University, El-Fayoum, Egypt, 2004.

69. Greve, M.H.; Kheir, R.B.; Greve, M.B.; Bøcher, P.K. Quantifying the Ability of Environmental Parameters to Predict Soil Texture Fractions Using Regression-Tree Model with GIS and LIDAR Data: The Case Study of Denmark. Ecol. Indic. 2012, 18, 1-10. [CrossRef]

70. Louis, P. Erosion Impacts on Soil and Environmental Quality: Vertisols in the Highlands Region of Ethiopia; University of Florida, Soil and Water Science Department: Gainesville, FL, USA, 2011.

71. Reijonen, I.; Metzler, M.; Hartikainen, H. Impact of Soil PH and Organic Matter on the Chemical Bioavailability of Vanadium Species: The Underlying Basis for Risk Assessment. Environ. Pollut. 2016, 210, 371-379. [CrossRef]

72. Kim, M.S.; Min, H.G.; Lee, S.H.; Kim, J.G. The Effects of Various Amendments on Trace Element Stabilization in Acidic, Neutral, and Alkali Soil with Similar Pollution Index. PLoS ONE 2016, 11, e0166335. [CrossRef]

73. Hilt, K.; Harrison, J.; Bowers, K.; Stevens, R.; Bary, A.; Harrison, K. Agronomic Response of Crops Fertilized with Struvite Derived from Dairy Manure. Water. Air. Soil Pollut. 2016, 227, 388. [CrossRef]

74. Diyabalanage, S.; Navarathna, T.; Abeysundara, H.T.K.; Rajapakse, S.; Chandrajith, R. Trace Elements in Native and Improved Paddy Rice from Different Climatic Regions of Sri Lanka: Implications for Public Health. Springerplus 2016, 5, 1864. [CrossRef] [PubMed]

75. FAO-UNDP. Land Resources Appraisal of Bangladesh; Technical Report 2; Agroecological Regions of Bangladesh, Food and Agriculture Organization: Rome, Italy, 1988; p. 570.

76. Navas, A.; Machín, J. Assessing Erosion Risks in the Gypsiferous Steppe of Litigio (NE Spain). An Approach Using GIS. J. Arid Environ. 1997, 37, 433-441. [CrossRef]

77. Grealish, G.J.; Ringrose-Voase, A.J.; Fitzpatrick, R.W.; Wong, M.T.F.; Winston, E.C. Soil Fertility Evaluation/Advisory Service in Negara Brunei Darussalam Volume 1-Soils and Land Suitability of the Agricultural Development Areas; Science Report 57/08; CSIRO Land and Water: Clayton, Australia, 2008.

78. Sahelian Solution Foundation (SASOL). Green grams Hand Book, A Guide to Farmers within Project Enhancing Food Security with Diversified Dry Land Farming Techniques in Kitui County. 2015. Available online: http://www.sasolfoundation.co.ke/2013 /wp-content/uploads/2015/02/Green-Grams-Manual.pdf (accessed on 16 May 2021).

79. Krishna, K.R. Agroecosystems of South India: Nutrient Dynamics, Ecology and Productivity; Universal-Publishers: Irvine, CA, USA, 2010.

80. Morton, F.; Smith, R.E.; Poehlman, J.M. The Mungbean; The College of Agricultural Sciences: University Park, PA, USA, 1982.

81. Mogotsi, K.K. Vigna radiata (L.) R.Wilczek. [Internet] Record from Protabase; Brink, M., Belay, G., Eds.; PROTA (Plant Resources of Tropical Africa/Ressources végétales de 1“Afrique tropicale): Wageningen, The Netherlands, 2006. Available online: http: / / database.prota.org/search.htm. (accessed on 21 May 2021).

82. Directorate Plant Production (DPP). Mung Bean Production Guideline; Department of Agriculture, Forestry and Fisheries: Pretoria, South Africa, 2016. Available online: www.nda.agric.za/docs/Brochures/MbeanpGUDELINS.pdf (accessed on 22 May 2021). 